Article

\title{
Integrating Life-Cycle Perspectives and Spatial Dimensions of Sewage Sludge Mono-Incineration
}

\author{
David Wagner ${ }^{1}$, Georg Neugebauer ${ }^{1, *} \mathbb{*}$, Florian Kretschmer ${ }^{2} \mathbb{( 1 )}$ and Gernot Stoeglehner ${ }^{1(1)}$ \\ 1 Institute of Spatial Planning, Environmental Planning and Land Rearrangement, University of Natural \\ Resources and Life Sciences, Peter Jordan-Strasse 82, 1190 Vienna, Austria; \\ david.wagner@boku.ac.at (D.W.); gernot.stoeglehner@boku.ac.at (G.S.) \\ 2 Institute of Sanitary Engineering and Water Pollution Control, University of Natural Resources and Life \\ Sciences, Muthgasse 18, 1190 Vienna, Austria; florian.kretschmer@boku.ac.at \\ * Correspondence: georg.neugebauer@boku.ac.at
}

Received: 31 March 2020; Accepted: 27 April 2020; Published: 29 April 2020

\begin{abstract}
The mono-incineration of sewage sludge offers new opportunities to develop wastewater infrastructure as regional energy cells and resource recovery sites. At the moment, the most important products of this technology are electric energy and heat from combined heat and power plants, as well as ash for the recovery of phosphorus. With spatial analysis, scenarios of the decentralized and centralized spatial organization of mono-incineration are assessed with regard to the energy balances of the incineration process, transport demands, and the possibility to accommodate excess heat in the surrounding spatial fabric, and these are evaluated by applying a multi-criteria analysis. The study is based on the Austrian case and shows that the utilization, not only of phosphorus and excess energy but also of other potential resources should be aimed for. The transport of sludge and the potential to use excess heat in the surrounding spatial fabric decide if centralized or decentralized scenarios are environmentally more feasible, whereas an "economy of scale" clearly gives leeway to the centralized options. Therefore, this study clearly demonstrates that introducing mono-incineration should not only focus on the process engineering itself but should also consider spatial planning provisions to reduce transport demands and to deliver excess energy to the surrounding spatial fabric.
\end{abstract}

Keywords: integrated spatial and energy planning; sludge to energy; phosphorous recovery; energy recovery; wastewater treatment; circular economy; secondary resources recovery

\section{Introduction}

In many countries across the world, discussions on the future perspectives of sewage sludge disposal have recently been gaining momentum [1]. In this context, the recovery of phosphorous is a key driver [2]. With a paradigm shift from end-of-pipe approaches (pollution removal) to resource-oriented approaches [3], wastewater treatment plants (WWTPs) generally tend to get seen as resource recovery facilities [4], including both phosphorous $(\mathrm{P})$ recovery and energy provision [5,6]. Concerning $\mathrm{P}$-recovery, the possibility to extract $\mathrm{P}$ from mono-incineration ash has been gaining attention in recent years [7]. Current research is investigating the understanding and creation of P-recovery strategies, and, as such, development has proceeded [8-10]. Mono-incineration is a technology utilizing the input of one basic incineration material, in this case, sewage sludge, and it is a highly energy intensive method. The end-products of mono-incineration are incineration ash and thermal energy. The ash is suitable for P-recovery, and the thermal energy can be further utilized for thermal or electrical energy supply. With regard to wastewater based energy supply, recent studies have shown two access points at WWTPs. First, to digest sewage sludge $[11,12]$ and, second, to recover thermal energy directly from the wastewater stream using heat pumps $[5,6,13]$. Hence, this paper concentrates on the energy 
and secondary resource recovery potentials $(\mathrm{P})$ from sewage sludge. To implement this, the existing infrastructure of WWTPs must be analyzed. Stoeglehner et al. (2011) [14] showed that spatial structures have an influence on two fields: the availability of resources and aspects of energy demand and supply potentials. The mono-incineration of sewage sludge also combines both fields: the recovery of phosphorus and the excess energy that could be utilized to supply thermal or electrical energy demand. To sustainably manage existing and new renewable energy resources, the spatial arrangement of energy generation (mono-incinerators) needs to be coordinated with energy demand. Energy generation and consumption is a complex and heterogeneous system that shows spatial differences. Current developments of energy- and resources recovery move in two different directions: centralized and decentralized solutions in the field of resource recovery and energy grids $[15,16]$.

The future goal of $\mathrm{P}$ and energy recovery needs to be analyzed from decentralized and centralized perspectives in order to allow for insights into the advantages and disadvantages of contrasting spatial approaches. Therefore, this work focuses on the spatial arrangements of future mono-incineration infrastructures and to assess energy, as well as P-recovery potentials with regard to the local and regional spatial fabric. Therefore, life cycle assessment approaches are combined with perspectives from integrated spatial and energy planning [17]. Integrated spatial and energy planning deals with the spatial dimensions of energy consumption and energy supply and aims to identify, preserve, and create energy efficient spatial structures [18]. Both energy consumption and the use of renewable energy sources are significantly determined by the respective spatial structures. The consistent implementation of the principles of functional mixing and density through appropriate site selection leads to compact, energy-efficient spatial structures that can generally also be very well supplied with renewable energies. A major task of integrated spatial and energy planning is that assessments for renewable energy potentials are supplemented by spatial planning considerations. In this way, the actually realizable potential because of spatial conditions can be narrowed down from natural, technical, and economic potentials [17].

Therefore, this paper deals with the issue of the (de-)centralization of mono-incineration from a system perspective within and beyond the wastewater and sludge treatment process. In this context, centralization specifically refers to a limited amount of big scale mono-incinerators that are centrally located within the spatial fabric. Hence, a central mono-incineration site is responsible for the sludge disposal of a wide range of surrounding WWTPs. Decentralization, in contrast, constitutes to the broader distribution in quantity of small scale mono-incinerators processing a limited range of surrounding WWTPs. In this context, all issues that are of general interest concerning energy and resource flow optimization in WWTPs and are not directly linked to the issue of mono-incineration are excluded. We recognize that a full process optimization of the treatment process would be of interest [11,12], but considering the current practice of sludge treatment and given the state of political and professional discussion, we focus on a holistic analysis of mono-incineration with stabilized sludge as starting point. Below, each of the three objectives are named, explained, and connected to the resulting research question (RQ).

Objective 1: To analyze the energy and P-recovery potentials produced from mono-incineration. From an integrated spatial or energy planning perspective, no solution has yet been found to use mono-incineration as a renewable thermal energy source and to define the locations of treatment plants, taking this criterion into consideration. That is why energy potentials, going along with the implementation of mono-incineration (fluidized bed), are to be analyzed. The goal is to find out whether, and to what extent, the pretreatment of sludge has an effect on the objective to utilize energy from mono-incineration as a potential renewable energy source for the future. Moreover, the objective is to assess the P-recovery potentials from mono-incineration ashes, resulting in the following research question (RQ 1): What is the energy and P-recovery potential for mono-incineration in Austria?

Objective 2: To analyze possible solutions for the spatial arrangement of mono-incinerators. The intention is to create different scenarios that represent both centralized and decentralized solutions that incorporate mono-incinerators in the existing sludge treatment system. The final goal is to 
establish a basis to evaluate the advantages and disadvantages of centralized versus decentralized solutions, resulting in the following research question (RQ 2): What are the spatial perspectives for mono-incineration in Austria?

Objective 3: This aims at creating a sound decision-making base. The intention behind research question three is to create useful evaluation criteria to evaluate possible scenarios for centralized and decentralized solutions for mono-incineration. The final intention is to compare advantages and disadvantages of each spatial solution from energy, environment, and an economical perspectives, resulting in the following research question (RQ 3): How can decision making between the scenarios developed be supported?

In order to elaborate on these research objectives and questions, a methodical structure was developed that is described in the following chapter and implemented using Austria as an example. From this case study, generally applicable points of discussion are presented, and conclusions drawn.

\section{Methods and Materials}

This section addresses the methodologies and materials used to answer each of the three research questions (RQ1-3). The basic characteristics of the analyzed system are listed in Figure 1. All estimations are based on the selection of WWTPs with a treatment capacity $\geq 50,000$ population equivalents (PE) in Austria, though WWTPs with PE $<50,000$ are not accounted. Figure 1 provides an overview of the five methods (energy balance, resource recovery estimation, scenario development, multiple criteria analysis, and a sensitivity analysis), their application, the presentation of results, and the respective sections of this paper.

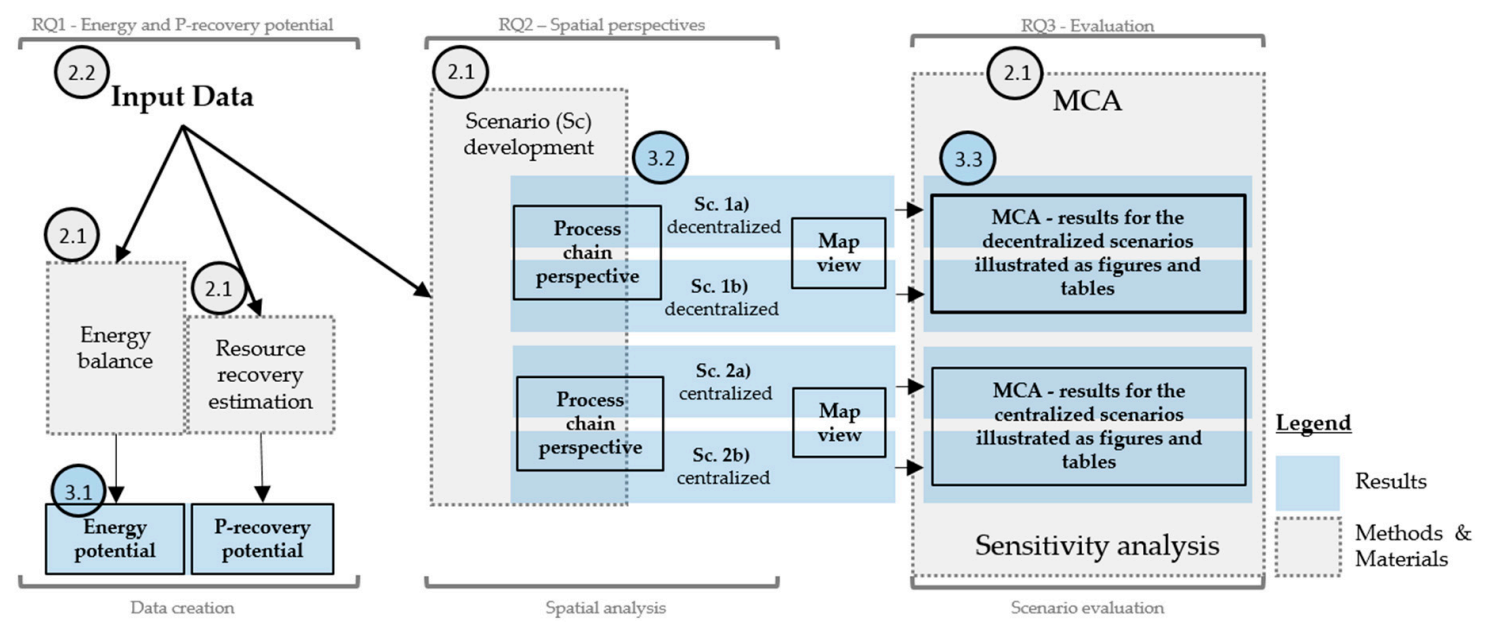

Figure 1. Overview to the five methods used for the case study, data flow, and paper structure. The numbers refer to the section of the paper where the item is discussed.

\subsection{Methods}

\subsubsection{Energy Balance and P-Recovery Potential}

\section{Energy Balance}

Figure 2 shows the main elements of the energy balance. The sludge treatment process chain functions as a starting point to consider relevant processes. Those that are accounted for the energy balance are marked with a green color, and the process that is not accounted is marked in black. Each process has a specific number to be recognized for the following descriptions. The objective is to work out, in detail, what effect the dry solids (DS) content of sludge has on the final products, as well as the electrical and thermal energy in combined heat and power processes, which means to estimate the differences in energy yield due to the DS content of the burning material (sludge). The final aim is to 
estimate an electrical and thermal energy potential that can be utilized for the future. The calculation principle is illustrated in Figure 2. The energy input needed to prepare the sludge (2) and (3) for incineration is subtracted from the energy output (4) of burning the sludge. A positive result (5) of this equation shows an energy potential, and a negative result (5) shows an energy expenditure.

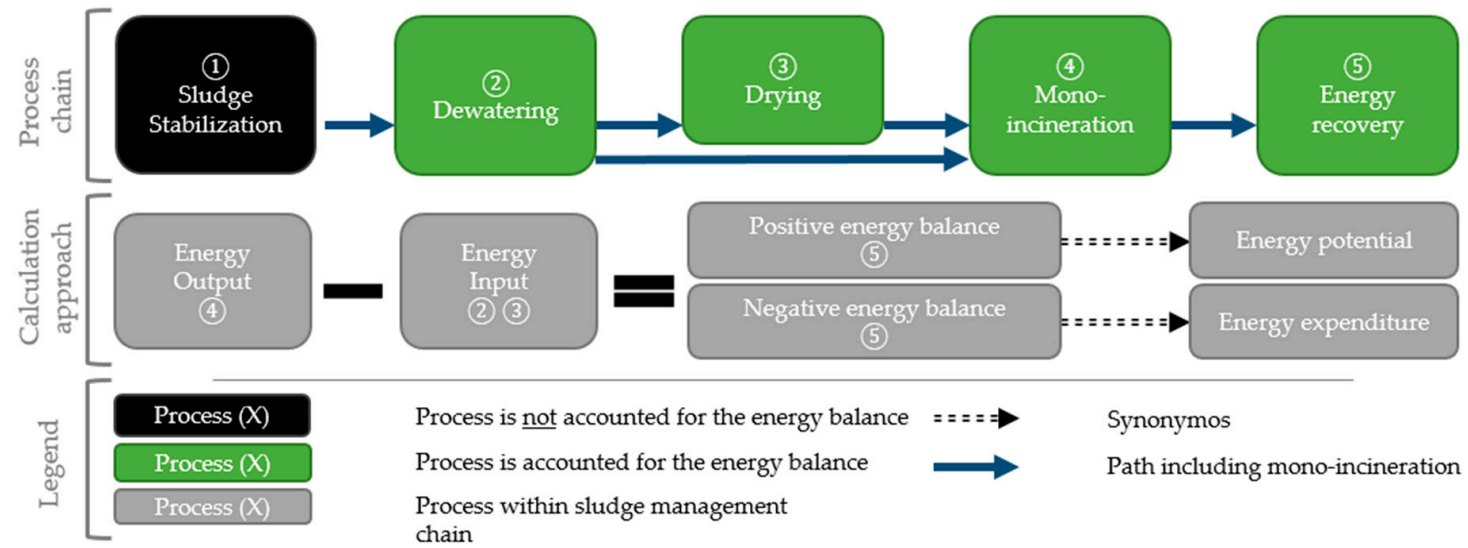

Figure 2. Overview to the processes accounted for and not accounted for the energy balance and respective basic calculation approach.

Stabilization (1) is not accounted for the energy balance for the following reason: In the targeted size class of WWTPs-above 50,000 population equivalents-we assumed anaerobic stabilization/digestion being applied to enable energy generation from biogas. The stabilization process itself and further energy generation from biogas production is not going to change if the sludge is mono-incinerated afterwards. Therefore, the process of sludge stabilization is not accounted for in the energy balance. Regarding dewatering (2), a mechanical drainage without heat value was assumed. This energy input is considered. The drying (3) of sludge is the process with the highest energy input within the pretreatment for incineration, so it is also included in the energy balance. Mono-incineration (4) is the major energy producing process and must therefore be accounted for the energy recovery (5), which represents the final output in regard to the process chain and is therefore accounted for. Four options for the pretreatment of sludge are shown in Table $1[19,20]$. The four options were derived to limit the set of possibilities to arrange the sludge pretreatment. There are two options without drying of sludge but dewatering to different DS content and two options that combine dewatering of sludge with the drying of sludge. This means that the sludge amount can be estimated with DS 35\%, DS 45\%, DS 70\%, and DS 90\%. The system border of the energy balance is the production of pure ash, and the energy input for P-recovery was not included because this is a new process-as are both central and decentral mono-incineration.

Table 1. Options for sludge pre-treatment for mono-incineration. DS: dry solids.

\begin{tabular}{cc}
\hline & Options for Sludge Pretreatment for Mono-Incineration \\
\hline Option & Characterization \\
\hline (1) & Dewatering sludge up to $35 \%$ DS \\
2 & Dewatering sludge up to $45 \%$ DS \\
3 & Dewatering sludge up to $45 \%$. Add a partially drying up to $70 \%$ DS \\
$\mathbf{4}$ & Dewatering sludge up to $45 \%$. Add a complete drying up to $90 \%$ DS \\
\hline
\end{tabular}


Resource Recovery Estimation

The objective was to assess the amount of incineration ash and corresponding quantity of phosphorus to be recovered for future use. The calculation was based on the following assumptions: Municipal incineration ash mainly consist of $60-120 \mathrm{~g} \mathrm{P} / \mathrm{kg}$ ash [10,21]. Thus, it is necessary to estimate P-recovery rates according to the different P-concentrations that are listed in Table 2.

Table 2. Assumptions to estimate the amount of mono-incineration ash and phosphorus (P)-recovery potential.

\begin{tabular}{cccc}
\hline \multicolumn{4}{c}{ Basic Data Used for the Resource Recovery Estimation } \\
\hline Characteristic & Unit & Value & Reference \\
\hline $\begin{array}{c}\text { Mean value of ash production from } \\
\text { mono-incineration }\end{array}$ & $(\%)$ & 41 & Krüger et al. [7] \\
\hline $\begin{array}{c}\text { P-concentrations used to estimate } \\
\text { P-recovery potential }\end{array}$ & $(\mathrm{g} \mathrm{P} / \mathrm{kg}$ ash $)$ & $60,90,120$ & Kraus et al. [10] \\
\hline Efficiency & $(\%)$ & 90 & Morf [8] \\
\hline
\end{tabular}

The amount of incinerations ash was based on the results of a survey focusing on the chemical substitution of mono-incineration ash [7]. The analysis of 21 WWTPs showed a mean amount of ashes resulting from mono-incineration with $41 \%$. P-recovery rates from mono-incineration ashes higher than $90 \%$ can be seen as standard today [8].

\subsubsection{Scenario Development-Spatial Analysis}

The presented structure is based on a deductive approach for scenario development according to Van Heijden (2005) and Schwartz (1991) [22,23]. The deductive approach is divided into the following three steps: (1) identification of subject and relevant factors, (2) prioritization of factors, and (3) the creation of scenarios $[22,23]$.

(1) Mono-incineration will have to expand for future sludge disposal because the existing mono-incineration capacities are not enough to deal with the future demand. This is the starting point to develop scenarios for decentralized and centralized solutions and to assess their feasibility. Both spatial solutions compound an integration process into the existing wastewater treatment system. Assumptions to do this are explained as follows. The existing infrastructure is expanded by the process of sludge transport, as shown in Figure 3.

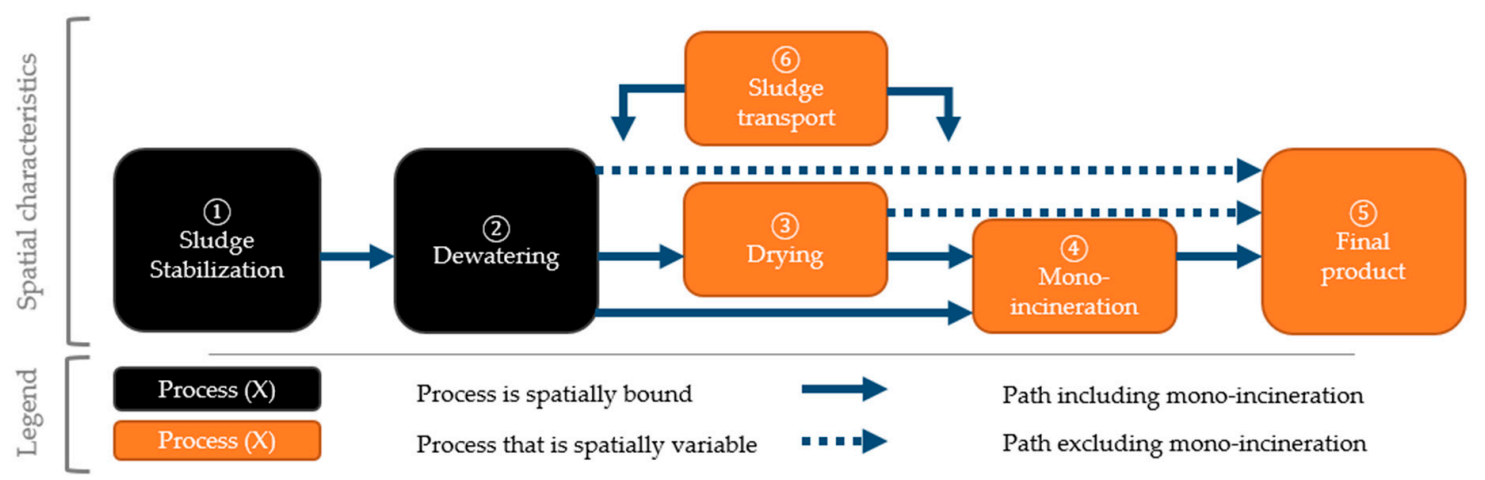

Figure 3. Spatially variable and bound processes considered for the scenario development. 
There are two options to include sludge transport in the existing process chain. Sludge can be directly transported before or after it is dried. Relevant factors to identify the subject are developed in consideration of spatial characteristics (level 1) and spatial criteria (level 2). Spatial characteristics contribute to the location of each process from the sludge treatment process chain and therefore only explain the spatial characteristic of the already existing system. In contrast to this, the spatial criteria refer to the measurable unit of sludge transport distance for each spatial solution. Table 3 lists the description for each spatial characteristic and spatial criteria.

Table 3. Relevant factors for the development of scenarios divided into level 1 (spatial characteristics) and level 2 (spatial criteria). WWTP: wastewater treatment plant.

\begin{tabular}{|c|c|}
\hline \multicolumn{2}{|r|}{ Relevant Factors } \\
\hline $\begin{array}{l}\text { Level 1-Spatial } \\
\text { Characteristics }\end{array}$ & Description \\
\hline $\begin{array}{l}\text { Location of Sludge } \\
\text { Production }\end{array}$ & $\begin{array}{l}\text { The location of sludge production determines the starting point to distribute the } \\
\text { burning material (sewage sludge). This is an important factor because of the } \\
\text { thermal potential related to the amount of sludge per location. The dewatering of } \\
\text { sludge is critical to make sludge transportable. }\end{array}$ \\
\hline Location of Drying & $\begin{array}{l}\text { The location of sludge drying has a further decisive impact on the transport effort. } \\
\text { The wetter the sludge (before drying), the more water needs to be transported to } \\
\text { the mono-incinerators. The more water remains in sludge, the more the mass (t/a) } \\
\text { and the higher the volume }\left(\mathrm{m}^{3} / \mathrm{a}\right) \text { of sludge that needs to be transported. Higher } \\
\text { volumes increase the number of transport-journeys, fuel consumption, transport } \\
\text { cost, and, finally, transport emissions. In summary, the location of drying plays a } \\
\text { potentially important role to evaluate the pros and cons of centralized and } \\
\text { decentralized solutions. }\end{array}$ \\
\hline $\begin{array}{l}\text { (4) } \\
\text { Location of } \\
\text { Mono-Incineration }\end{array}$ & $\begin{array}{l}\text { The position of mono-incineration is a key factor for the determination of the } \\
\text { spatial solutions. Material and energy flows change according to the position of } \\
\text { incineration. The focus is to create centralized and decentralized scenarios. }\end{array}$ \\
\hline $\begin{array}{l}\text { Location of the Final } \\
\text { Products }\end{array}$ & $\begin{array}{l}\text { The final outlets are thermal energy and incineration ash. Thermal energy can be } \\
\text { utilized within the internal infrastructure or be distributed to external heat } \\
\text { consumers. As the incineration ash is the basic source for further P-recovery, } \\
\text { the location of primary ash management starts at the mono-incineration plant. }\end{array}$ \\
\hline $\begin{array}{c}\text { Level 2-Spatial } \\
\text { Criteria }\end{array}$ & Descriptions \\
\hline $\begin{array}{l}\text { (6) } \\
\text { Sludge Transport } \\
\text { Distance }\end{array}$ & $\begin{array}{l}\text { To the transport distance via lorry }(24 \mathrm{t}) \text { from the WWTPs to the decentralized or } \\
\text { centralized locations for mono-incineration. In principle the following applies: } \\
\text { Environmental pollution is rising with a growing distance. }\end{array}$ \\
\hline
\end{tabular}

(2) In general, level 1, the spatial characteristics of the already existing system, is prioritized because those factors represent the basic setting to be rearranged. As a consequence of this, level 2, the spatial criteria of the developed scenarios, represents the results that have to be further adjusted. This basic scheme is transformed into assumptions for the creation of both the decentralized and centralized scenario.

(3) The objective is to develop possible scenarios for centralized as well as decentralized solutions for mono-incineration. The framework of the basic sludge management process chain is taken as a starting point for restructuring. The principle is to distinguish locally bound and flexible processes to find possible access points in the existing system. Those access points have to be further sorted out by the minimum sludge amount needed to run a mono-incinerator. Afterwards, the limitations by quantity of incineration facilities further limit possible locations. The spatial criterion of sludge transport distance is finally used to optimize the selection. A detailed description of the procedure is summarized in Tables 4 and 5 . 
Table 4. Assumptions for the development of a decentralized scenario divided into levels 1 and 2.

\begin{tabular}{|c|c|}
\hline \multicolumn{2}{|r|}{ Decentralized Scenario. } \\
\hline Level 1-Spatial Characteristics & Description \\
\hline $\begin{array}{l}\text { 1. Spatial characteristic of } \\
\text { relevant sludge treatment } \\
\text { processes }\end{array}$ & It is distinguished whether a process is locally bound or flexible. \\
\hline $\begin{array}{l}\text { 2. Sludge amount } \\
\geq 2000 \text { t DS/a }\end{array}$ & $\begin{array}{l}\text { The WWTP does achieve the required sludge amount to run a } \\
\text { mono-incinerator. Therefore, the location of the WWTP represents a } \\
\text { possible location for mono-incineration. }\end{array}$ \\
\hline $\begin{array}{l}\text { 3. Sludge amount } \\
<2000 \text { t DS/a }\end{array}$ & $\begin{array}{l}\text { The WWTP does not achieve the required minimum amount of yearly } \\
\text { sludge amount to run a mono-incinerator. Therefore, the location of this } \\
\text { WWTP is not suitable to run a mono-incinerator. The WWTP functions as } \\
\text { a supplier WWTP for the closest possible location for mono-incineration. }\end{array}$ \\
\hline 4. Regional coverage & $\begin{array}{l}\text { No limitation in quantity of mono-incinerators. Each region with enough } \\
\text { sludge accumulation receives a mono-incinerator. }\end{array}$ \\
\hline Level 2-Spatial Criteria & Description \\
\hline 5. Transport distance & Sludge transport should be reduced as much as possible. \\
\hline \multicolumn{2}{|r|}{ Centralized Scenario } \\
\hline Level 1-Spatial Characteristic & Description \\
\hline $\begin{array}{l}\text { 1. Spatial characteristic of } \\
\text { relevant sludge treatment } \\
\text { processes }\end{array}$ & It is distinguished whether a process is locally bound or flexible. \\
\hline 2. Sludge amount & $\begin{array}{l}\text { The top } 10 \text { WWTPs that produce most of the sludge represent the basic } \\
\text { selection (Supplementary Material, Table S13). }\end{array}$ \\
\hline 3. Regional coverage & $\begin{array}{l}\text { Restriction in the quantity of mono-incinerators. The country is separated } \\
\text { into } 4 \text { regions (A, B, C, D) that receive one mono-incinerator each. }\end{array}$ \\
\hline Level 2-Spatial Criteria & Description \\
\hline 4. Transport distance & Sludge transport should be reduced as much as possible. \\
\hline
\end{tabular}

\subsubsection{Multiple Criteria Analysis (MCA)}

Using a multiple criteria-analysis (MCA), the benefit of each scenario was evaluated. The evaluation is based on the following three categories: (1) energy, (2) environmental impact, and (3) costs. For each category, evaluation criteria were set and used to examine the advantages and disadvantages of possible solutions. Finally, sensitivity analysis was used to distinguish the influence of the weighting of each evaluation criterion on the results of the evaluation. The methodology of the MCA was used to evaluate the scenarios. An MCA is not a static evaluation tool, as it can be developed for different purposes [24,25]. The MCA developed for this present work functioned as an evaluation tool for different scenarios. A Swiss study [26] served as a guideline to form the evaluation structure. The basic procedural structure for the MCA is shown in Figure 4. 


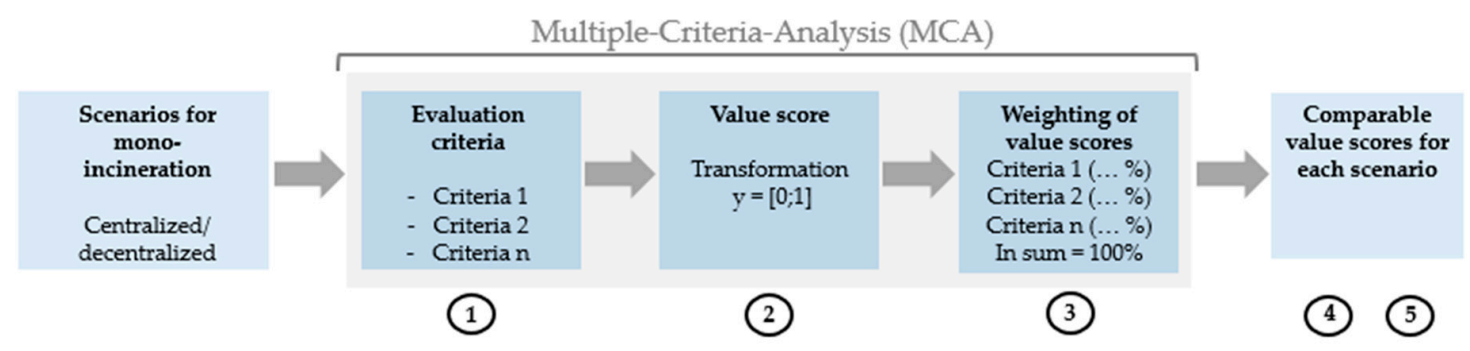

Figure 4. Procedural steps for evaluation of scenarios via a multiple criteria analysis (MCA). 1. Quantify all values for each evaluation criteria in each scenario. 2 . Transform to value scores, $y=[0 ; 1]$. 3 . Weigh the values. 4. Summarize the value scores in each scenario. 5. Compare and interpret the results. Adapted after Bättig et al.

The MCA is composed of following three parts [26,27]:

1. Definition of Evaluation Criteria: Considered criteria and indicators are used for evaluation of scenarios.

2. Value in Use: Values for each indicator are transformed into a value in use. The scale for value in use is defined as $\mathrm{y}=[0 ; 1]$. Transformed indicators can be used to compare different evaluations among each other.

3. Weighting Factor: Each of the criteria is assigned with a weighting factor. The sum of all weighting factors is $100 \%$.

Definition of Evaluation Criteria

Evaluation criteria are split up in three categories: (1) energy, (2) environmental impact, and (3) cost and associated with an indicator. An indicator expresses each evaluation criteria in a measurable unit. The evaluation criteria and the correlating indicators are listed in Table 6.

Table 6. Summary of evaluation criteria listed in the categories energy 1 (En1), energy 2 (En2), environment 1 (Env1), environment 2 (Env2), Cost 1 (Co1), Cost 2 (Co2), Cost 3 (Co3), and associated indicators with units used for the MCA.

\begin{tabular}{|c|c|c|c|}
\hline No. & Evaluation Criteria & Indicator & Unit \\
\hline \multicolumn{4}{|c|}{ Category 1-Energy } \\
\hline En1 & $\begin{array}{c}\text { Reduced consumption of nonrenewable } \\
\text { energy resources }\end{array}$ & Energy utilization potential & $(\mathrm{GWh} / \mathrm{a})$ \\
\hline En2 & $\begin{array}{l}\text { Increase in consumption of } \\
\text { nonrenewable energy resources }\end{array}$ & $\begin{array}{l}\text { Additional thermal energy } \\
\text { demand for sludge drying }\end{array}$ & $(\mathrm{GWh} / \mathrm{a})$ \\
\hline \multicolumn{4}{|c|}{ Category 2-Environmental impact } \\
\hline Env1 & Transport distance & Emissions & $\left(\mathrm{CO}_{2}\right.$ e./a $)$ \\
\hline Env2 & $\begin{array}{l}\text { Substituted } \mathrm{CO}_{2} \text { emissions from fossil } \\
\text { fuels }\end{array}$ & Emissions & $\left(\mathrm{CO}_{2}\right.$ e./a $)$ \\
\hline \multicolumn{4}{|c|}{ Category 3-Cost } \\
\hline Co1 & Economic risk & Investment cost & $(€)$ \\
\hline $\mathrm{Co} 2$ & Economic risk & Specific cost & $(€ / \mathrm{t} D S)$ \\
\hline $\operatorname{Co3}$ & Economic risk & Transport cost & $(€ / a)$ \\
\hline
\end{tabular}

Detailed descriptions for each evaluation criterion and corresponding value score can be found in Chapter 1 Supplementary Materials Table S1-S8. 
Value in Use (Value Score)

Each evaluation criterion needed to be transformed into a useable value score. Therefore, quantitative measures of each indicator were transformed into a scale without a dimension to allow for comparison. For this work, the scale 0 was defined as most negative impact and 1 was defined as the most positive impact. Numerical measurements of indicators were transformed with the linear equation, $\mathrm{y}=[0 ; 1]$, using a utility function.

Weighting Factor (Weighting of Value Scores)

The different weighting schemes were used to check the influence of evaluation criteria to the results of the MCA. In addition to the standard weighting, two alternatives were created in order to make visible how different value judgements might have influenced the results of the MCA. Standard weighting: assumes that environmental criteria determine future solutions. In contrast, Alternative A assumes that economic criteria determine future solutions. Alternative B is the neutral weighting scheme that was based on equal distribution to the weighting of all evaluation criteria. The specific weighting for each evaluation criteria in accordance to the three different weighting schemes is summarized in Table 7.

Table 7. Standard and alternative weighting for each evaluation criteria.

\begin{tabular}{ccccc}
\hline No. & Perspective & $\begin{array}{c}\text { Standard } \\
\text { Weighting }\end{array}$ & $\begin{array}{c}\text { Alternative } \\
\text { A }\end{array}$ & $\begin{array}{c}\text { Alternative } \\
\text { B }\end{array}$ \\
\hline & Energy & $40 \%$ & $25 \%$ & $29 \%$ \\
En1 & Reduced consumption of nonrenewable & $20 \%$ & $12.5 \%$ & $14.3 \%$ \\
& energy resources & & \\
En2 & Increase in consumption of nonrenewable & $20 \%$ & $12.5 \%$ & $14.3 \%$ \\
& energy resources & $40 \%$ & $25 \%$ & $29 \%$ \\
Env1 & Environmental impact & $20 \%$ & $12.5 \%$ & $14.3 \%$ \\
Env2 & Transport distance & $12.5 \%$ & $14.3 \%$ \\
& Substituted CO2 emissions from fossil fuels & $20 \%$ & $43 \%$ \\
Co1 & Economic perspective & $20 \%$ & $50 \%$ & $14.3 \%$ \\
Co3 & Investment cost & $6.67 \%$ & $16.7 \%$ & $14.3 \%$ \\
\hline & Specific cost & $6.67 \%$ & $16.7 \%$ & $14.3 \%$ \\
\hline
\end{tabular}

\subsection{Materials}

This paper concentrates on the energy and resources recovery potentials from sewage sludge and implements recently described methods, using Austria as an example. More precisely, the Austrian Federal Waste Management Plan 2017 stated to focus on P recovery from sewage sludge treatment in Austria. By 2030, 65\%-85\% of sewage sludge produced in Austria should be used for P-recovery. The method proposed as best choice to achieve this aim is the fluidized bed mono-incineration [28]. The Federal Ministry for Sustainability and Tourism (BMNT) claims that there is a need to investigate centralized and decentralized options for P-recovery. Thus far, mono-incineration (fluidized bed) for sewage sludge disposal is used in Vienna, but there is no energy or P-recovery infrastructure yet. Consequently, this calls for investigation into solutions for the basic spatial arrangement of mono-incinerators and to consider the size of WWTPs appropriate for P-recovery. As BMNT specifically targets WWTPs with a treatment capacity larger than 50,000 PE to investigate in solutions for future decentralized or centralized P-recovery, this was accepted for the present research too [28]. Moreover, current incineration capacities cannot cope with the future demand. Therefore, challenges are related, among others, to the spatial arrangement of new mono-incinerators. In this context, the amount of phosphorus to be potentially recovered from the ash needs to be estimated. In addition to P-recovery, the potential to utilize thermal energy produced by mono-incineration in a contrasting spatial context 
needs to be analyzed, too. Electricity can be transported over much larger distances compared to heat, so only heat was included in this spatial analysis. As there is only one operating mono-incinerator in Austria right now (Vienna), the future goal of P- and energy recovery needs to be analyzed from decentralized and centralized perspectives. That is why the focus of this work was to concentrate on the spatial arrangement of future mono-incineration infrastructure and to assess energy and P-recovery potentials in Austria.

The input data for present study comprised the "Waterbase-UWWTD" database [29] offered by the Urban Waste Water Treatment Directive (UWWTD). The UWWTD is the pioneering regulatory tool used to collect data about the treatment and discharge of the European Union countries' wastewater flows. It offers, among others, information about PE and discharge points of all European WWTPs. The UWWTD does not provide specific data about sludge amounts, rather providing data about wastewater discharges in general. However, sludge flows relative to agglomeration points are estimated from the Waterbase-UWWTD database (2017). Sludge quantities with different DS content are required for all considered WWTPs to determine the influence of varying sludge treatment options (1-4) on the energy balance, the P-recovery potentials, and the transport intensity per scenario. For this reason, simplified estimations of sludge quantities per WWTP and DS content were carried out. The software Excel was used for the implementation of all calculations in present work. The system boundaries for the MCA are as follows:

- Transport distance was considered as a loaded journey to the incineration plant and a journey back to the WWTP with no load, as we assumed that sludge transport vehicles cannot be used for other transport demands without cleaning and hygienization.

- Changes in sludge density according to DS content were neglected.

- Thermal energy produced by mono-incineration is first utilized, if possible, to dry the sludge.

\section{Results}

The results of this work intend to contribute to the development of new sludge treatment strategies. Here, the results from the above described methodologies are presented: first, the energy and P-recovery potential, followed by the outcomes from the spatial analysis, and, finally, the results from the MCA.

\subsection{Energy and P-Recovery Potential}

The selection of relevant WWTPs with PE $>50,000$ from the Waterbase dataset of the UWWTD resulted in a list of 41 WWTPs. Named WWTPs and the estimated yearly production of sludge for each WWTP are shown in Supplementary Materials, Table S12. Information concerning the results of the energy balance of all 41 WWTPs are summarized in the following Table 8. Results are split up to three different WWTP size classes.

Table 8. Results of the energy balance of 41 WWTPs divided by size class and pre-treatment options 1-4. Energy potentials are given in electrical energy (electr.) and thermal (therm.) energy. The calorific value $(\mathrm{Cv})$ is displayed for each treatment option [30].

\begin{tabular}{|c|c|c|c|c|c|c|c|c|c|}
\hline \multicolumn{10}{|c|}{ Energy Balance } \\
\hline \multirow{2}{*}{$\begin{array}{c}\text { Size Class } \\
(\mathrm{PE})\end{array}$} & \multirow{2}{*}{$\begin{array}{l}\text { WWTPs } \\
\text { (quantity) }\end{array}$} & \multicolumn{2}{|c|}{$\begin{array}{c}\text { Option } 1 \\
\text { (DS 35\%) } \\
\text { Cv: } \sim 3 \mathrm{MJ} / \mathrm{kg}\end{array}$} & \multicolumn{2}{|c|}{$\begin{array}{c}\text { Option } 2 \\
\text { (DS 45\%) } \\
\text { Cv: } \sim 5 \mathrm{MJ} / \mathrm{kg}\end{array}$} & \multicolumn{2}{|c|}{$\begin{array}{c}\text { Option 3 } \\
\text { (DS 70\%) } \\
\text { Cv: } \sim 8.5 \mathrm{MJ} / \mathrm{kg}\end{array}$} & \multicolumn{2}{|c|}{$\begin{array}{c}\text { Option } 4 \\
\text { (DS 90\%) } \\
\text { Cv: } \sim 12 \mathrm{MJ} / \mathrm{kg}\end{array}$} \\
\hline & & $\begin{array}{c}\text { electr. } \\
\text { (GWh/a) }\end{array}$ & $\begin{array}{l}\text { therm. } \\
\text { (GWh/a) }\end{array}$ & $\begin{array}{c}\text { electr. } \\
\text { (GWh/a) }\end{array}$ & $\begin{array}{l}\text { therm. } \\
\text { (GWh/a) }\end{array}$ & $\begin{array}{c}\text { electr. } \\
\text { (GWh/a) }\end{array}$ & $\begin{array}{l}\text { therm. } \\
\text { (GWh/a) }\end{array}$ & $\begin{array}{c}\text { electr. } \\
\text { (GWh/a) }\end{array}$ & $\begin{array}{l}\text { therm. } \\
\text { (GWh/a) }\end{array}$ \\
\hline $50,000-100,000$ & 18 & 10 & 36 & 13 & 47 & 12 & 41 & 12 & 42 \\
\hline $100,001-150,000$ & 13 & 13 & 44 & 16 & 57 & 14 & 50 & 15 & 51 \\
\hline$>150,000$ & 10 & 46 & 162 & 60 & 210 & 52 & 183 & 53 & 186 \\
\hline Sum & 41 & 69 & 242 & 90 & 314 & 78 & 273 & 80 & 279 \\
\hline
\end{tabular}


Each size class provided information about the number of respective WWTPs. The electrical and thermal energy potentials are given for each size class and pretreatment option. The 41 WWTPs were found to handle approximately $62 \%(13,912,495 \mathrm{PE})$ of the total treatment capacity in Austria. Therefore, the federal aim to utilize $65 \%-85 \%$ of Austria's sludge for P-recovery cannot be achieved by concentrating on WWTPs with PE $>50,000$ if it is assumed that the sludge resources are distributed equally to all PE in Austria. An overall estimate of 69-90 GWh/a of electrical energy potential and 242-314 GWh/a of thermal energy potential from mono-incineration is not yet used in Austria. The thermal energy potentials are approximately 250\% higher than the electrical energy potentials. Therefore, it seems feasible to investigate solutions that utilize the thermal energy from mono-incineration in district heating systems. This crucial difference is caused by the higher thermal energy offtake efficiency ( $\mathrm{n} 70 \%$ ) in contrast to the efficiency for electrical energy offtake ( $\Omega 20 \%$ ). With regards to the energy balance, the pretreatment strategy without the drying of sludge (option 2) but dewatering up to DS $45 \%$ results in the highest energy yield. Reaching DS $45 \%$ in dewatering is optimistic, but according to the BAT (Best Available Techniques), a reference document for waste incineration [19], this is possible and should be developed from best available technology as a future standard for dewatering. The energy yields with partial or completely drying of sludge (options 3 and 4) as pretreatment differed only slightly by approximately $2 \%(6 \mathrm{GWh} / \mathrm{a})$ at $273-279 \mathrm{GWh} / \mathrm{a}$. These results refuted the assumption that the increasing caloric value of completely dried sludge could result in a higher energy yield. The almost equal energy yield could be traced back to an exponentially rising energy consumption for the complete drying of sludge to a DS content of $90 \%$. Furthermore, it is necessary to highlight the correlation between size of the treatment plant and the energy potential in Table 8. Almost two thirds (66\%) of the energy could be produced by the 10 WWTPs bigger than 150,000 PE.

In parallel to the energy potential, the P-recovery potential is visualized for the three size classes in Table 9. In addition to this, the ash production and the correlating amount of phosphorus are given in accordance with different $\mathrm{P}$-concentrations in mono-incineration ash.

Table 9. Results for the P-recovery potentials according to size categories of WWTPs and mono-incineration ash P-concentration categories.

\begin{tabular}{ccccccc}
\hline \multicolumn{7}{c}{ P-Recovery Potential with Recovery Efficiency $\mathbf{9 0 \%}$} \\
\hline Size Category & WWTPs & PE & $\begin{array}{c}\text { Ash } \\
\text { Production }\end{array}$ & $\begin{array}{c}\mathbf{6 0} \mathbf{~ g ~ P / k g} \\
\text { ash }\end{array}$ & $\begin{array}{c}\mathbf{9 0} \mathbf{~ g ~ P / k g} \\
\text { ash }\end{array}$ & $\begin{array}{c}\mathbf{1 2 0} \mathbf{~ g ~ P / k g} \\
\text { ash }\end{array}$ \\
\hline (PE) & & (Sum) & (t/a) & $\mathbf{( t ~ P / a )}$ & $\mathbf{( t ~ P / a )}$ & $\mathbf{( t ~ P / a ) ~}$ \\
\hline $50,000-100,000$ & 18 & $1,290,911$ & 8867 & 479 & 718 & 958 \\
$100,001-150,000$ & 13 & $1,583,166$ & 10,875 & 587 & 881 & 1174 \\
$>150,000$ & 10 & $5,791,857$ & 39,784 & 2148 & 3222 & 4297 \\
\hline Sum & 41 & $8,665,934$ & 59,526 & 3214 & 4822 & 6429 \\
\hline
\end{tabular}

If the sewage sludge of all 41 WWTPs is mono-incinerated, a total amount of almost 60,000 $\mathrm{t}$ ash per year is produced. Corresponding with the energy potentials, two thirds (67\%) of the ash can be related to the sludge from the 10 biggest WWTPs in Austria. The mono-incineration ashes contain between 3214 and $6429 \mathrm{t}$ P/a that are not recovered yet. The middle size class $(100,001-150,000)$ handles $18 \%$ of the P-resources distributed to 13 WWTPs. The smallest size class $(50,000-100,000)$ handles $15 \%$ of the P-resources distributed to 18 WWTPs. If Austria only focuses on WWTPs with PE $>50,000$, it must investigate solutions to manage these approximately 60,000 $\mathrm{t}$ of mono-incineration ash per year. Mono deposits or P-recovery facilities that are capable of dealing with this load would need to be investigated. The phosphate concentration of mono-incineration ash is crucial for the feasibility of P-recovery. Finally, the goal for future P-recovery represents promising potentials, but it is also important to combine this aim with an efficient recovery of energy. 


\subsection{Spatial Analysis}

This work presents four basic spatial scenarios, two decentralized and two centralized ones, to include the mono-incineration process in the existing sludge treatment process chain. The four basic scenarios are shown in Figure 5, and each basic scenario considers four variants of sludge treatment in regard to the level of sludge dryness, resulting in a total variety of eight decentralized (D1-D8) and eight centralized (C1-C8) scenarios that are presented in Figures 6 and 8. The pretreatment processes of sludge stabilization and dewatering are spatially bound, so they will remain at the existing locations at Austria's WWTPs. As sludge needs to be transported for each of the scenarios, there is no option to change the basic pretreatment of sludge. The process of sludge drying is highly energy intensive and must be analyzed on a case-specific basis. According to the energy balance, the need for a drying process is questionable because the energy yield is lowered by the energy consumption from the drying process. If sludge is dried, it would be reasonable to combine the location of drying and the location of mono-incineration to use the existing thermal energy from the mono-incineration for the drying process. If the thermal energy from the mono-incineration process cannot be utilized to dry the sludge, an external thermal energy source is needed, which would be a disadvantage.

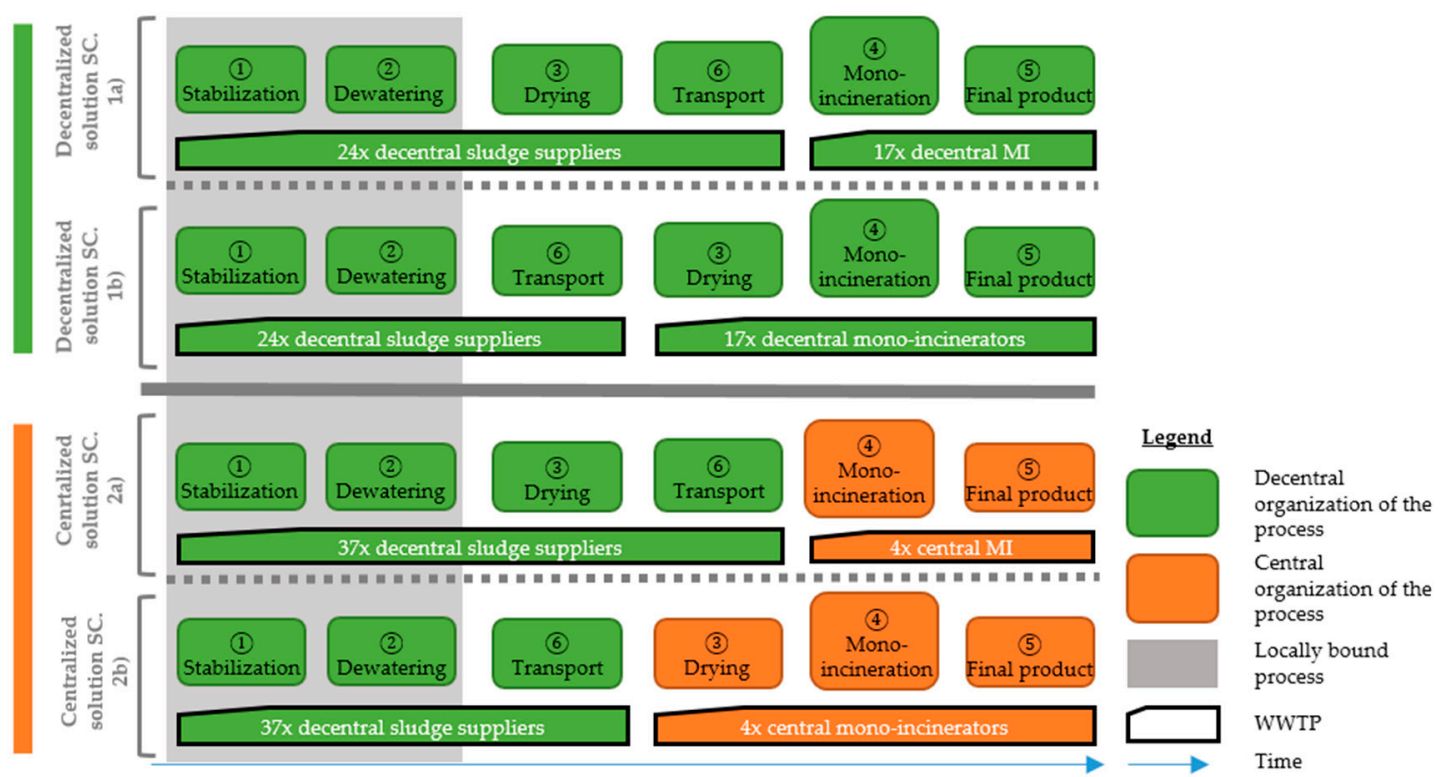

Figure 5. Results of the basic spatial perspectives for the mono-incineration process. Characteristics of scenario $1,2(\mathbf{a})$, and $2(\mathbf{b})$.

\subsubsection{Decentralized Scenarios $1 \mathrm{a}, \mathrm{b}$}

For the creation of decentralized scenarios, there was no restriction in the quantity of mono-incinerators. Seventeen possible decentralized mono-incineration locations resulted due to the minimum DS amount of $2000 \mathrm{t} / \mathrm{a}$ to run a mono-incinerator. The remaining 24 WWTPs with DS amounts $<2000 \mathrm{t} / \mathrm{a}$ would have to supply the 17 WWTPs that operate a mono-incinerator with sludge. Building on this, Figure 6 illustrates the eight decentralized scenarios (D1-D8), including sludge pretreatment options $1-4$, in detail. 


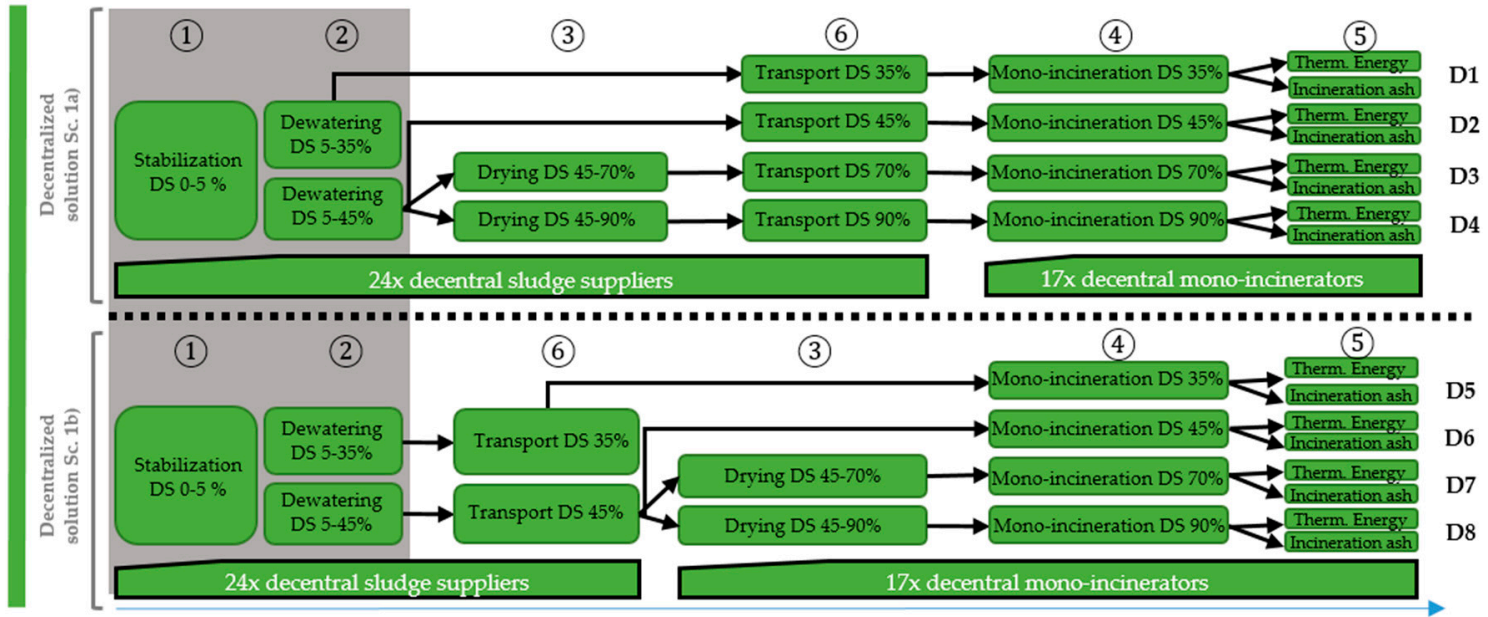

Figure 6. Decentralized and scenarios 1(a), (b) including sludge pre-treatment options 1-4.

Sludge from the 24 supplier WWTPs is distributed to the 17 locations for mono-incineration. Pretreatment options 1-4 are related to the different treatment options D1-D4 and D5-D8. Before sludge is transported, it is dewatered up to DS 35\% (D1 and D5) or up to DS $45 \%$ (D2, D3, D4, D6, D7, and D8). Dewatered sludge can be directly transported to the mono-incinerator (D1, D2, D5, and D6) or be further dried up to DS 70\% (D3 and D7) or DS 90\% (D4 and D8) before it is transported. With an increasing level of DS content, the volume of sludge that needs to be transported to the mono-incinerator decreases. Hence, the transportation effort is highest with D1 and D5 and lowest for D4. The volume of ash produced by mono-incineration of sludge does not change with different levels of DS content. The water and the organic parts of the sludge combust, while incineration and the remaining inorganic part (ash) are the same for each option (D1-D8).

The thermal energy yield changes with the level of DS content of the sludge. The thermal energy yield is highest without a drying device but is also the highest possible level of dewatering up to DS 45\% (D2 and D6). The positive effect of scenario 1a is the reduction of transport effort due to a reduced sludge volume. This is only possible in case that sludge is dried before it is transported to the mono-incinerator. Nevertheless, the required external heat demand at each of the 24 supplier WWTPs in order to dry the sludge before it is transported is disadvantageous. It is not possible to use the thermal energy produced by the mono-incinerator because the process of drying is situated at a different location. The thermal energy produced at the 17 decentral mono-incinerators (D1, D2, D3, and D4) is the highest possible because no thermal energy is taken to dry the sludge. The high thermal energy yield at the top locations is an advantage only for the 17 WWTPs with decentral mono-incinerators. The external heat demand to dry the sludge represents additional costs for the 24 decentral supplier WWTPs. Those costs could be diminished by combining sludge drying and mono-incineration.

Therefore, opportunity costs between the supplier WWTPs and the mono-incinerator WWTPs evolve for D1, D2, D3, and D4. The main difference for scenario $1 \mathrm{~b}$ is the location of the drying process. In contrast to scenario $1 \mathrm{a}$, scenario $1 \mathrm{~b}$ locally combines the process of drying with the process of mono-incineration. Therefore, the thermal heat produced by the mono-incineration process can be utilized to dry the sludge, and there is no need for an external thermal energy supply. Another consequence is that the transportation effort cannot be reduced as much as in D3 and D4 from scenario 1a because the sludge can only be dewatered up to DS $45 \%$. The advantage of scenario $1 \mathrm{~b}$ in contrast to scenario $1 \mathrm{a}$ is the possibility to utilize produced thermal energy from the mono-incineration process to further dry the sludge up to DS 70\% or DS 90\% (D7 and D8). A disadvantage is the lower reduction of sludge amount due to limitation in dewatering capacities. Therefore, the sludge amount can be reduced to a maximum level of DS $45 \%$ before it is transported. Thirteen of the seventeen decentralized mono-incinerators have sludge supplier WWTPs. The remaining four mono-incinerators 
function as single units without sludge suppliers. The 13 decentralized mono-incineration clusters and corresponding supplier WWTPs are mapped in Figure 7.

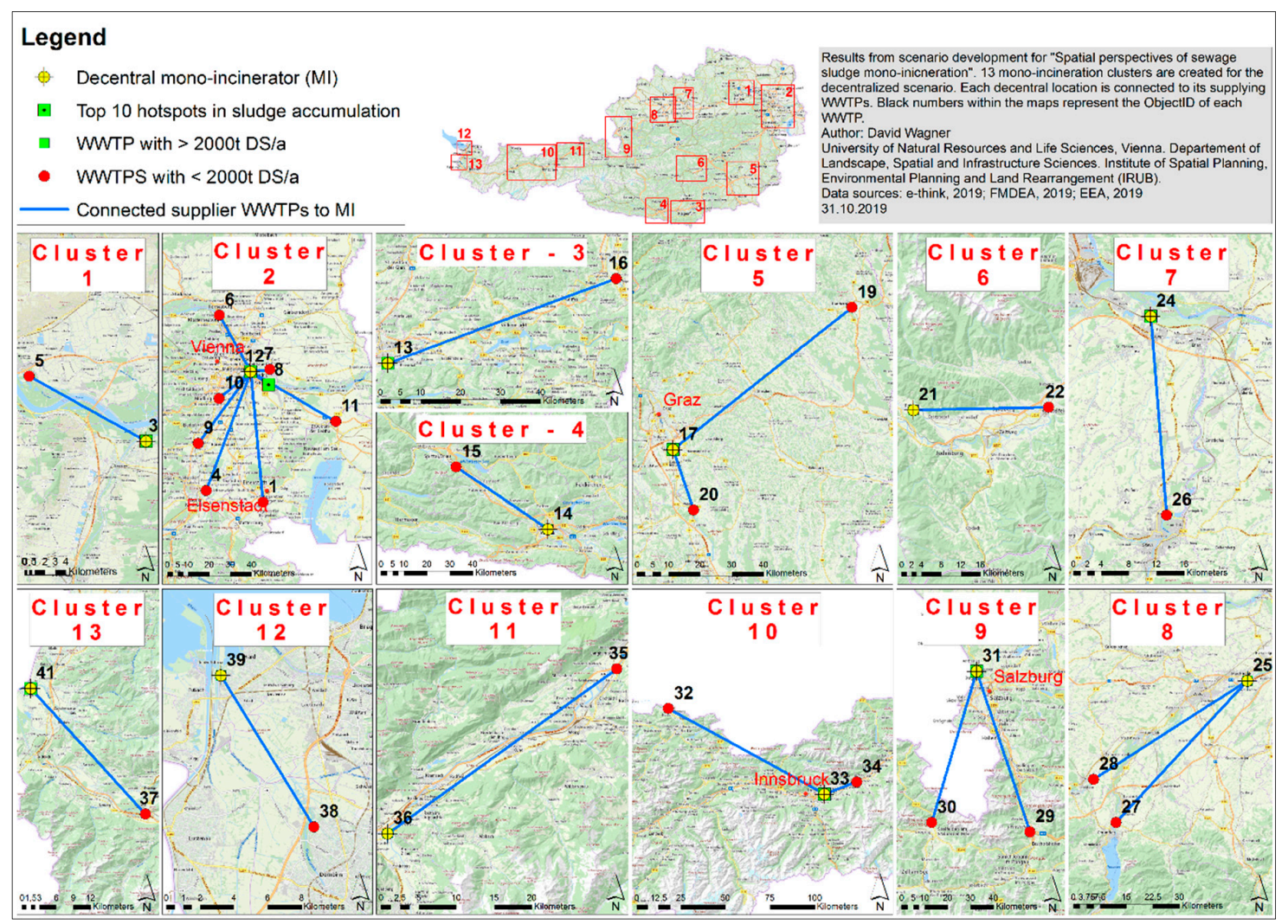

Figure 7. Resulting mono-incineration clusters for the decentralized solution; scenarios 1a,b.

\subsubsection{Centralized Scenarios $2 \mathrm{a}, \mathrm{b}$}

The basic procedural arrangement is comparable with the decentralized scenarios, but the number of sludge suppliers and mono-incinerators was found to change. Moreover, the distance between supplier and mono-incinerator is changing too. Due to the intention to reduce the amount of mono-incinerators as much as possible, the centralized solution results in four centralized WWTPs that operate a mono-incinerator. These four top locations are Vienna, Linz, Graz, and Innsbruck. The decision for Wien, Linz, and Graz being top locations was obvious. The three locations represent the top three in sludge accumulation (level 1). In addition, each city covers one region (A, B, and D) of Austria (level 1). Considering the sludge accumulation, the fourth top location should be set in Salzburg, ARA Siggerwiesen. However, Salzburg does not cover the western region (C) and is, therefore, not classified as top location. Since Innsbruck covers the western region (C) and its WWTPs sludge capacity is within the top 10 of sludge production (Supplementary Materials, Table S13), it was ranked before Salzburg. Figure 8 shows that the remaining 37 WWTPs function as sludge suppliers for the four centralized locations for mono-incineration. 


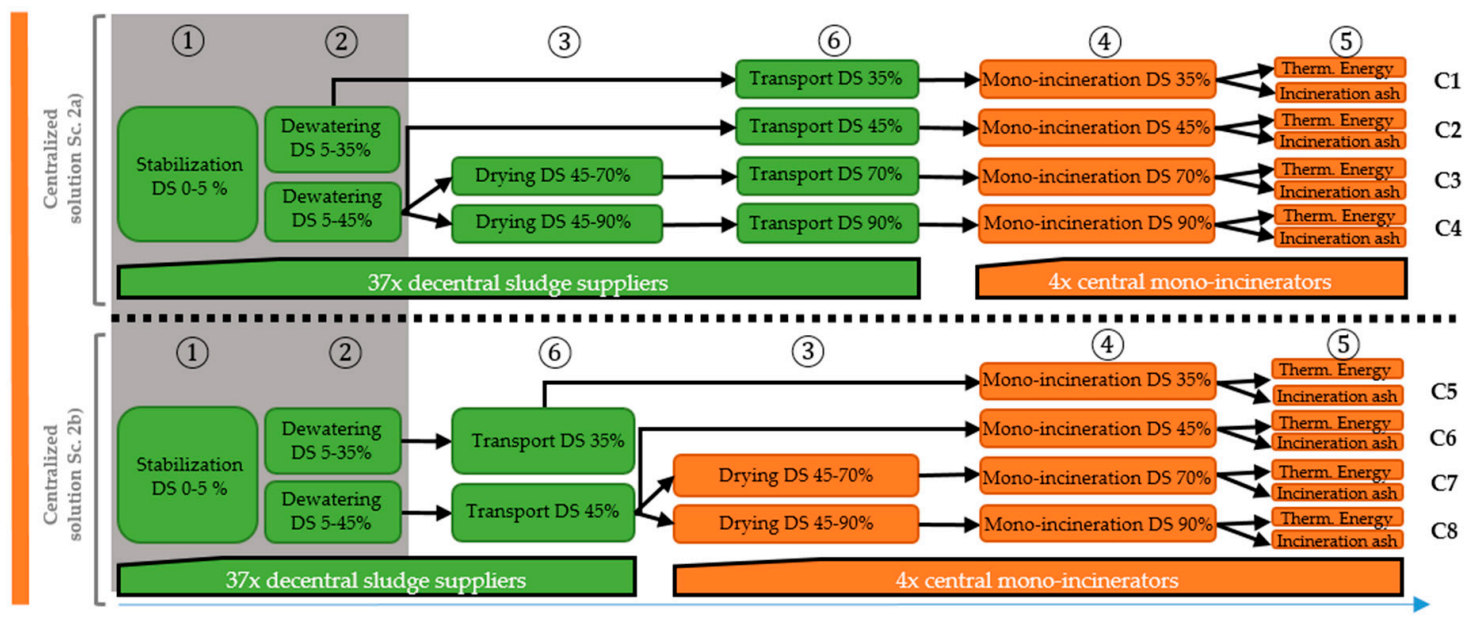

Figure 8. Centralized scenarios 2(a), (b) including sludge pre-treatment options 1-4.

Before sludge goes into the transport, it is further pretreated by drying ( $\mathrm{C} 3$ and $\mathrm{C} 4$ ) or directly transported to the four central top locations for mono-incineration ( $\mathrm{C} 1, \mathrm{C} 2, \mathrm{C} 5$, and $\mathrm{C} 6)$. The positive effect in the drying procedure for $2 \mathrm{a}$ is the reduction of sludge volume to be transported with the decreasing amount of water. The disadvantage is the external heat demand at each of the 37 supplier WWTPs to dry the sludge ( $\mathrm{C} 3$ and $\mathrm{C} 4$ ). It is not possible to use the thermal energy produced by mono-incinerators since the process of drying is located far away. The thermal energy produced at the top locations is as high as possible because little thermal energy is taken to dry the sludge $(\mathrm{C} 1, \mathrm{C} 2, \mathrm{C} 3$, and C4). The high thermal energy yield is an advantage only for WWTPs of the top locations. The external heat demand to dry the sludge represents additional costs for the 37 decentral supplier WWTPs. Those costs could be diminished by combining sludge drying and mono-incineration. Therefore, opportunity costs between the 37 supplier WWTPs and the four mono-incinerator WWTPs evolve in case of 2a. In contrast to scenario 2a, sludge is not dried before, but, after, it arrives at the top location for $2 \mathrm{~b}$. As the drying device is only located at the four top locations, 37 supplier WWTPs must transport sludge with DS 35\% (C5) or DS 45\% (C6, C7, and C8). Consequently, the sludge volume that is transported is higher than in scenario 2a. The 37 supplier WWTPs only have to operate the stabilization and dewatering. It is possible to use the thermal energy produced by mono-incinerators to dry the sludge (C7 and $\mathrm{C} 8$ ). The thermal energy produced at the top locations is lower than in scenario 2a because parts of the produced thermal energy are used to dry the sludge. No opportunity costs between the supplier WWTPs and the mono-incineration WWTPs evolve in this case. The four centralized mono-incineration clusters are mapped in Figure 9. 


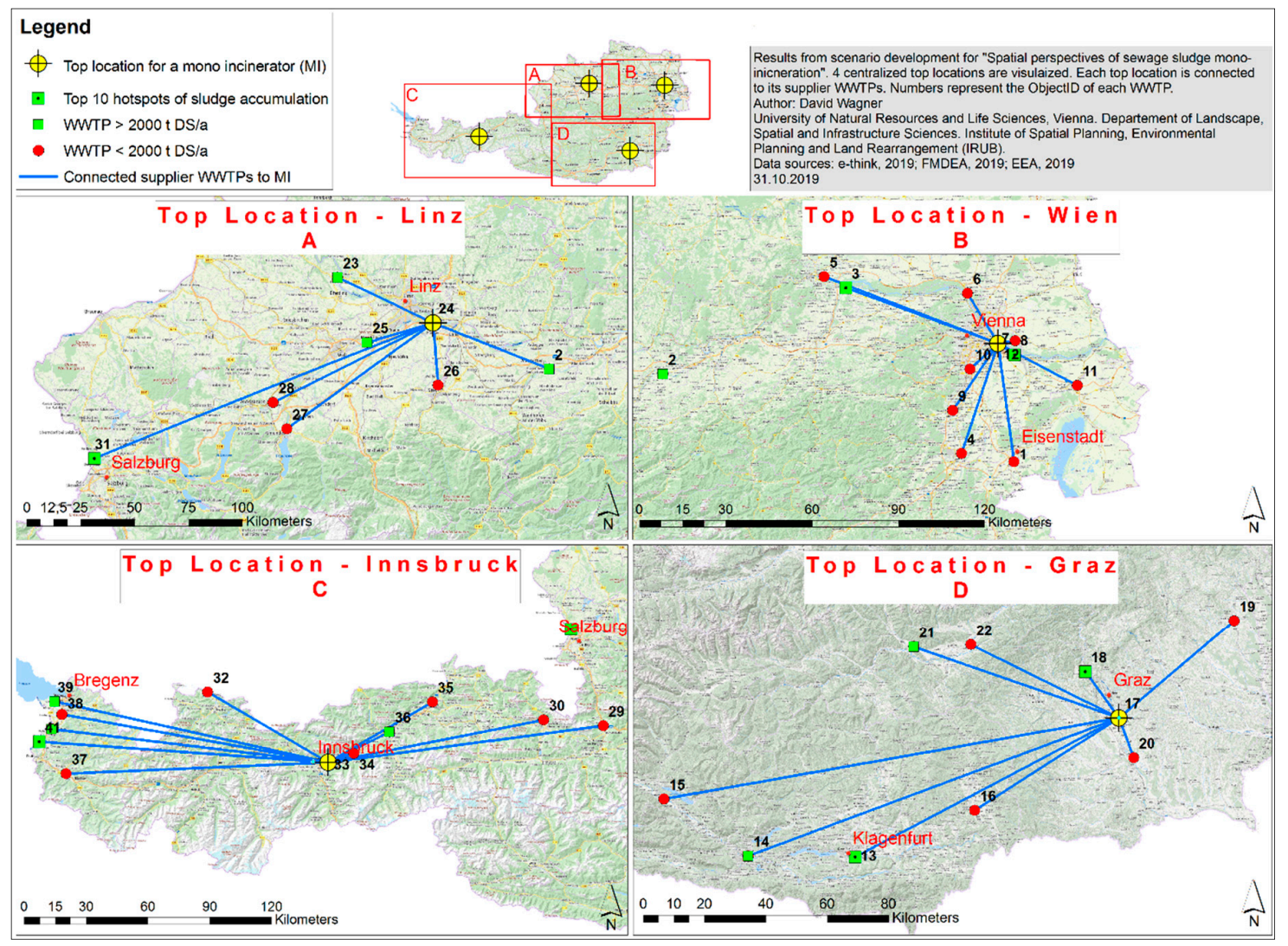

Figure 9. Resulting mono-incineration clusters for the centralized solution; Scenario 2(a,b).

\section{3. $M C A$}

This section shows results from the evaluation of scenarios by the MCA. First, the overall results from the standard weighting are shown. Second, results from the sensitivity analysis give an overview to changes in results due to varying weighting schemes alternatives A and B. The results shown below are presented in the following structure. The four basic spatial solution opportunities, two decentralized $(1 a, b)$ and two centralized solutions $(2 a, b)$ are extended by the sludge treatment options $1-4$, resulting in eight decentralized (D1-D8) and eight centralized (C1-C8) scenarios, as shown in Figures 6 and 8. For each scenario, the number of points achieved according to the MCA is displayed.

\subsubsection{Overall Results}

Overall results for the standard weighting of the MCA are shown in Table 10 and Figures 10 and 11. Results are presented according to the structure described above. Weighted results range from a total score of 0.60 ( $\mathrm{C} 1$ and $\mathrm{C} 5$ ) to 0.72 (D6). Therefore, the maximum difference in total score is $20 \%$. 
Table 10. Overall results of the MCA with the standard weighting.

\begin{tabular}{cccccccccc}
\hline Indicator & No. & D1 & D2 & D3 & D4 & D5 & D6 & D7 & D8 \\
\hline Energy utilization potential & $($ En1) & 0.14 & 0.15 & 0.14 & 0.16 & 0.15 & 0.16 & 0.16 & 0.16 \\
External energy demand & $($ En2) & 0.20 & 0.20 & 0.13 & 0.10 & 0.20 & 0.20 & 0.20 & 0.20 \\
Transport emissions & $($ Env1) & 0.16 & 0.17 & 0.18 & 0.19 & 0.16 & 0.17 & 0.17 & 0.17 \\
Emission savings & $($ Env2) & 0.09 & 0.13 & 0.13 & 0.16 & 0.10 & 0.13 & 0.12 & 0.12 \\
Investment costs & $($ Co1) & 0.00 & 0.00 & 0.00 & 0.00 & 0.00 & 0.00 & 0.00 & 0.00 \\
Specific costs & $($ Co2) & 0.01 & 0.01 & 0.01 & 0.01 & 0.01 & 0.01 & 0.01 & 0.01 \\
Transport cost & $($ Co3) & 0.04 & 0.05 & 0.06 & 0.06 & 0.04 & 0.05 & 0.05 & 0.05 \\
\hline Total score & & 0.65 & 0.70 & 0.65 & 0.67 & 0.66 & 0.72 & 0.71 & 0.71 \\
\hline & & $\mathbf{C 1}$ & $\mathbf{C 2}$ & $\mathbf{C 3}$ & $\mathbf{C 4}$ & $\mathbf{C 5}$ & $\mathbf{C 6}$ & $\mathbf{C 7}$ & $\mathbf{C 8}$ \\
\hline Energy utilization potential & $($ En1) & 0.20 & 0.20 & 0.20 & 0.20 & 0.20 & 0.20 & 0.20 & 0.20 \\
External energy demand & $($ En2) & 0.20 & 0.20 & 0.06 & 0.00 & 0.20 & 0.20 & 0.20 & 0.20 \\
Transport emissions & $($ Env1) & 0.00 & 0.04 & 0.10 & 0.12 & 0.00 & 0.04 & 0.04 & 0.04 \\
Emission savings & $($ Env2) & 0.13 & 0.17 & 0.18 & 0.20 & 0.13 & 0.17 & 0.15 & 0.15 \\
Investment costs & $($ Co1) & 0.02 & 0.02 & 0.02 & 0.02 & 0.02 & 0.02 & 0.02 & 0.02 \\
Specific costs & $($ Co2) & 0.05 & 0.05 & 0.05 & 0.05 & 0.05 & 0.05 & 0.05 & 0.05 \\
Transport cost & $($ Co3) & 0.00 & 0.01 & 0.03 & 0.04 & 0.00 & 0.01 & 0.01 & 0.01 \\
\hline Total score & & 0.60 & 0.70 & 0.65 & 0.64 & 0.60 & 0.70 & 0.68 & 0.68 \\
\hline
\end{tabular}
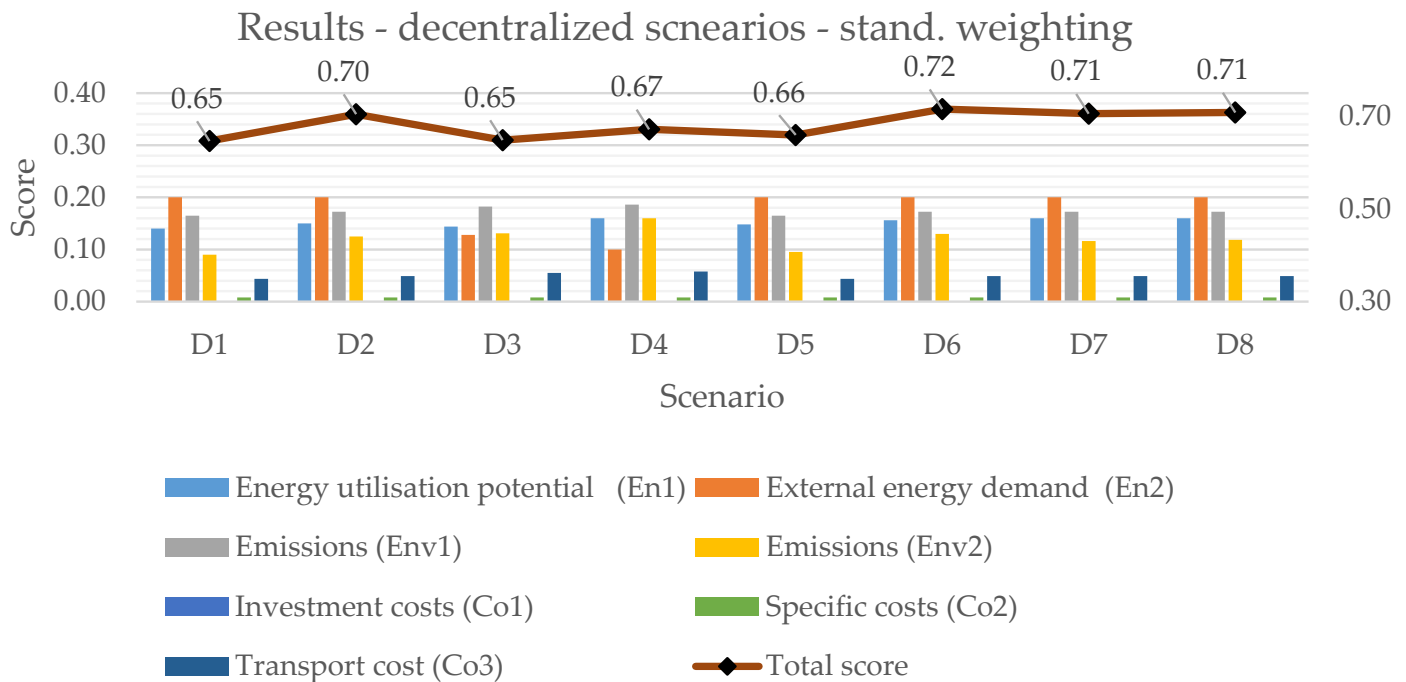

Figure 10. Overall results with the standard weighting for decentralized scenarios $(1 a, b)$. The score (left y-axis) of each evaluation criteria (En1, En2, Env1, Env2, Co1, Co2, and Co3) is shown for all scenarios (D1-D8). The total score (right y-axis) for each scenario is shown by line above the evaluation criteria bars. 

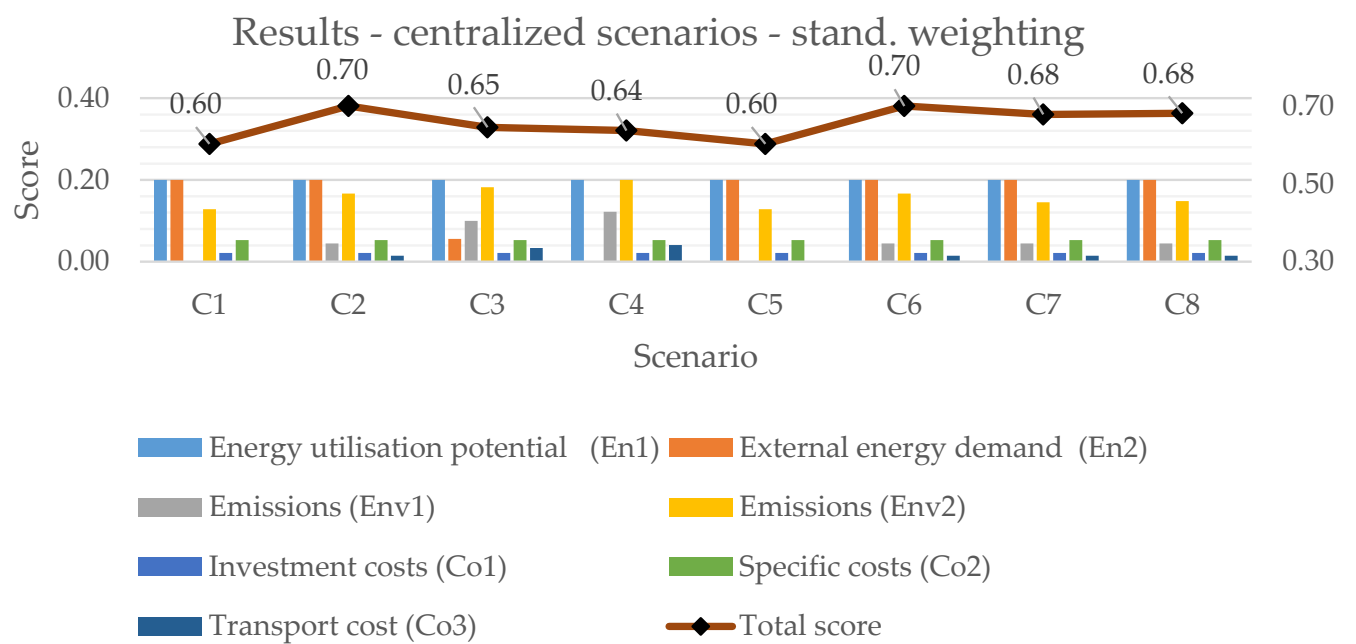

Figure 11. Overall results with the standard weighting for decentralized scenarios $(2 \mathrm{a}, \mathrm{b})$. The score (left y-axis) of each evaluation criteria (En1, En2, Env1, Env2, Co1, Co2, and Co3) is shown for all scenarios (C1-C8). The total score (right y-axis) for each scenario is shown by line above the evaluation criteria bars.

\section{Energy (En1 and En2)}

Only for the centralized scenarios was the potential to use thermal energy (En1) for efficient district heating systems $100 \%$. In contrast, Table 10 shows the score for En1 is, on average, $24 \%$ lower for the decentralized solutions. The difference in score goes back to missing energy consumers in the reachable surrounding of some decentral mono-incineration locations. The thermal energy at each of the 17 decentralized locations is lower than at the four centralized locations. With a lower thermal energy capacity at each of the 17 locations, the possible distance to supply thermal energy consumers is limited for each case. This results in a surplus of thermal energy at 9 of the 17 possible decentralized locations due to a limited thermal energy demand in a radius between 500 and $1000 \mathrm{~m}$ around the mono-incinerator. The main reason for this is the lack of thermal energy consumers in the immediate area surrounding the mono-incinerators. The four centralized locations accumulate higher thermal energy capacities, resulting in a supply radius of more than $3 \mathrm{~km}$. The thermal energy demand within this $3 \mathrm{~km}$ radius was found to be, in each case, more than 100\%, thus resulting in a constant score of 0.20. The external heat demand for sludge drying (En2) only occurs for solutions D3, D4, C3, and C4. These solutions lose scores as more external heat is needed to dry the sludge before sludge transport. The highest score is achieved if there is no external heat demand to dry sludge for the spatial solutions D1, D2, D5, D6, D7, D8, C1, C2, C5, C6, C7, and C8. Table 10 shows a constant score for each of the solutions, meaning that there is no external heat demand to dry sludge. Table 10 further shows that since the scenario C4 calls for the highest external heat demand ( $278 \mathrm{GWh} / \mathrm{a})$ to dry up sludge, it receives the lowest score. Nevertheless, the drying of sludge has a positive effect on the transport emissions (Env1) with a score of 0.12 .

\section{Environmental Impact (Env1, Env2)}

Table 10 shows that the highest total scores for transport emissions (0.17-0.19) are found within the decentralized solutions D2-D4. The transport distance for sludge by lorry are lower for the decentralized scenarios, meaning that the average $\mathrm{CO}_{2}$ emissions are lower for the decentralized scenarios than for the centralized scenarios. The produced $\mathrm{CO}_{2}$ equivalents $\left(\mathrm{CO}_{2} \mathrm{e}\right)$ due to sludge transport are far higher with the centralized solutions than with the decentralized solutions. The average production of $\mathrm{CO}_{2} \mathrm{e}$ from sludge transport is $273 \mathrm{t} \mathrm{CO}_{2} \mathrm{e} / \mathrm{a}$ for the decentralized solutions. The average production of $\mathrm{CO}_{2} \mathrm{e}$ with the centralized solutions is $1545 \mathrm{tCO}_{2} \mathrm{e} / \mathrm{a}$ and, therefore, $465 \%$ higher than the decentralized solutions. The highest score (Env1) from the decentralized solutions is D4, and from 
the centralized solutions is C4, which is displayed in a correlation between lower transport emissions due to a smaller amount of sludge that needs to be transported. The negative side effect is the need for thermal energy to dry sludge before it is transported. Despite the large distance between the mono-incineration and the production site of the sludge, the highest external heat demand is needed for D4 and C4. As the location of mono-incineration is not close to the production of sludge, an external heat source is needed, subsequently, D4 and C4 show the highest external heat demand. The lowest total scores can be found at the centralized solutions with the highest transport effort and, therefore, the highest yearly production of $\mathrm{CO}_{2} \mathrm{e}$, which is around $2060 \mathrm{t}$ for $\mathrm{C} 1$ and $\mathrm{C} 5$. With regards to the substitution of fossil fuels for energy generation (Env2) in the surrounding areas, it is important to highlight that Env2 is created from the En1 data. The decentralized and centralized scenarios both offer an average energy potential of around $280 \mathrm{GWh} / \mathrm{a}$. The only difference between the contrasting spatial solutions is the energy consumption potential, as shown above for En1. The utilization potential is 100\% for the centralized scenarios and $76 \%$ for the decentralized scenarios. In total, the estimated energy supply potential of $280 \mathrm{GWh} / \mathrm{a}$ represents the potential to substitute approximately 70,000 $\mathrm{t} \mathrm{CO}_{2} \mathrm{e} / \mathrm{a}$ for the decentralized and 88,000 $\mathrm{tCO}_{2} \mathrm{e} / \mathrm{a}$ for the centralized scenarios (Env2). Therefore, the transport emissions play a minor role for the overall emission balances if the excess heat is used to heat the surrounding urban fabric substituting fossil energy.

Cost (Co1, Co2, and Co3)

Table 10 shows a clear tendency that the decentralized solutions require higher investment costs for mono-incineration infrastructures than the centralized solutions (Co1). According to the applied methodology, this results in a zero score for all decentralized scenarios for Co1. The total investment costs including 17 investments for decentralized mono-incinerators range is approximately 200 Mill $€$, and, for the centralized solutions, a total expected cost of 137 Mill $€$ including four investments have to be considered. The expected investment costs for the decentralized solutions are $46 \%$ more expensive. The specific cost of sludge disposal for the decentralized solutions are higher than the centralized solutions ( $\mathrm{Co} 2$ ). The expected specific costs for decentralized solutions range, on average, between 470 and $230 € / t$ DS for the centralized solutions, whereas the expected specific costs for the decentralized solution are, on average, 100\% more expensive. The sludge transport costs from the supplier WWTPs to the centralized mono-incinerators are higher (Co3). The average transport costs for decentralized scenarios range around 2 Mill $€ / a$ and more than 6 Mill $€ / a$ for the centralized scenarios.

\subsubsection{Sensitivity Analysis}

Sensitivity analysis was used to check the influence of evaluation criteria to the results of the MCA. In addition to the standard weighting, two alternatives were observed. Changes in the results of the MCA in accordance to the weighting schemes are summarized in Table 11.

Table 11. Overview to the ranking results of all three weighting schemes. The total score and resulting rank are illustrated for each weighting scheme and scenario. The top scores are highlighted in green color.

\begin{tabular}{cccccccccc}
\hline \multicolumn{8}{c}{ Overall Ranking-Standard Weighting (SW), Alternative A (Alt. A), Alternative B (Alt. B) } \\
\hline & D1 & D2 & D3 & D4 & D5 & D6 & D7 & D8 & \\
\hline \multirow{3}{*}{ Total score } & 0.65 & 0.70 & 0.65 & 0.67 & 0.66 & 0.72 & 0.71 & 0.71 & SW \\
\cline { 2 - 11 } & 0.50 & 0.55 & 0.52 & 0.54 & 0.51 & 0.55 & 0.55 & 0.55 & Alt. A \\
\cline { 2 - 11 } & 0.54 & 0.58 & 0.55 & 0.57 & 0.55 & 0.59 & 0.59 & 0.59 & Alt. B \\
\hline \multirow{4}{*}{ Total score } & C1 & C2 & C3 & C4 & C5 & C6 & C7 & C8 & \\
\cline { 2 - 11 } & 0.60 & 0.70 & 0.65 & 0.64 & 0.60 & 0.70 & 0.68 & 0.68 & SW \\
\cline { 2 - 11 } & 0.52 & 0.60 & 0.60 & 0.61 & 0.52 & 0.60 & 0.59 & 0.59 & Alt. A \\
\hline
\end{tabular}


Partly equal rankings between alternatives $A$ and $B$ are shown in Table 11 . The centralized scenarios are more advantageous if the weighting focus is set towards the economical characteristics (Alt. A) or if it is distributed equally (Alt. B) among all evaluation criteria. If the weighting power is focused towards the cost (Alt. A) or it is equally distributed, the centralized solutions keep the pole position $(\mathrm{C} 2, \mathrm{C} 6, \mathrm{C} 7$, and C8). This ranking shows the impact of the weighting scheme. The decentralized solutions are more advantageous only if the focus is set on the energy criteria (En1 and En2) and environmental criteria (Env1 and Env2). A closer look at the scores for alternative A and B is shown in the Supplementary Materials with Tables S10 and S11 and Figures S1-S4. A closer look to the total numbers of the MCA is given in the Supplementary Materials with Table S9.

\subsubsection{Summary of the MCA}

The scenario evaluation by the MCA resulted in a trade-off situation. Therefore, this research question was answered in accordance to the three alternative weighting schemes from the analysis. The decentralized scenarios were ranked first only when a high weighting was given to the environmental (Env1) and energy (En1 and En2) evaluation criteria. Whereas, if the weighting scheme favored the evolving costs or the energy utilization potentials, the centralized scenarios were ranked first. The centralized scenarios showed a higher heat consumption maximum $(100 \%)$ than the decentralized scenarios (approximately 76\%). However, the average production of $\mathrm{CO}_{2} \mathrm{e} / \mathrm{a}$ caused by sludge transport is $1545 \mathrm{t} \mathrm{CO} 2 / \mathrm{a}$, which is $465 \%$ higher with the centralized solutions than with the decentralized solutions ( $273 \mathrm{t} \mathrm{CO} / \mathrm{a})$. Due to the fact that the energy utilization rate can be up to $100 \%$ for the centralized scenarios, in contrast to up to $76 \%$ for decentralized scenarios, the emission savings (Env2) can be up to $26 \%$ (approximately 18,000 $\mathrm{t} \mathrm{CO}_{2} \mathrm{e} / \mathrm{a}$ ) higher for the centralized scenarios if the full potential is exhausted. The decentralized solutions are less advantageous with most cost criteria. Investment costs of approximately 200 Mill $€$ and average specific costs of $470 € / t$ DS cannot compete with the lower investment costs of 137 Mill $€$ and on average specific cost of $230 € / t$ DS for the centralized solutions. Hence, the investment and the specific cost for mono-incineration of sludge are far higher with the decentralized solutions, whereas the transport costs for the decentralized scenarios result in only one third of the transport costs from the centralized scenarios.

\section{Discussion}

Here, the above-described results are discussed, including implications and possible further investigations necessary to develop holistic P-recovery strategies for Austria and beyond with regard to (1) the energy and P-recovery potential and (2) the outcomes from the spatial perspectives assessment in relation to the results from the MCA. Finally, (3) the strengths and limitations of the methodology are also addressed.

\subsection{Energy- and P-Recovery}

The recovery potential for electrical energy is around $69-90 \mathrm{GWh} / \mathrm{a}$, in contrast to the recovery potential for thermal energy, which is around $242-314 \mathrm{GWh} / \mathrm{a}$. In case of an existing thermal energy demand in the direct surroundings, this remarkable difference in energy recovery potential from mono-incineration can considerably influence the overall energy balance of the system. Therefore, it is necessary to utilize the thermal energy from mono-incineration in district heating systems. These measures on the supply side enable the use of sustainable energy that otherwise could not be utilized. The concept of energy efficiency using district heating is essential for a future low-carbon energy system [31]. Due to a seasonal change in thermal energy demand but a constant sewage sludge production over the year, the time management of energy by controlling the supply as well as energy storage becomes necessary. As stabilized sludge can be temporally stored, a seasonally higher generation of heat and power in the winter months is possible and useful for sustainable energy systems. 
Moreover, it is crucial for any further analysis to combine resources and energy recovery potentials in order to receive a more holistic picture of the situation. These considerations might also include a re-thinking of existing sewage sludge treatment schemes from an integrated perspective. According to Hao et al. [11], the direct incineration of sewage sludge without today's widely applied pre-step of anaerobic digestion appears to be more favorable for both financial and energetic reasons.

If the energy balance is considered from the perspective of mobility, results can be put in relation to the associated diesel consumption of sludge transport. The highest possible diesel consumption for the decentralized scenarios is about 100,000 L/a compared to 635,000 L/a for the centralized scenarios. The calorific value of diesel is $10 \mathrm{kWh} /$ liter [32]. This means that the transport energy consumption can be estimated at between 1 and $6.4 \mathrm{GWh} / \mathrm{a}$. In all cases, the energy and $\mathrm{CO}_{2}$ balances of the mono-incineration remain positive if the excess energy of heat and electricity can be meaningfully used in the energy system.

Approximately 60,000 t/a of mono-incineration ash must be managed in the future. Ash management means to control the amount of ash produced by mono-incineration at each location. Management strategies for future ash treatment represent an important field of investigation. Basic options for ash management are firstly to store the ash, secondly to sell the ash, and thirdly to transport it to a P-recovery location or run P-recovery on site. The P-recovery potential of 3200-6400 t P/a has the potential to substitute around $18 \%-36 \%$ of the yearly consumption of mineral fertilizers in Austria [33]. In contrast to the value derived from the present work, Egle et al. (2016) declared P-concentrations in mono-incineration ashes at only between 60 and $100 \mathrm{~g} \mathrm{P} / \mathrm{kg}$ [2]. Consequently, it is reasonable to question a rate of substitution of $36 \%$. The measurement of data concerning the current chemical composition of sewage sludge from a variety of locations of Austrian WWTPs would help to make the planning process more precise. In addition, it is of fundamental importance to generate data on the real P-concentration of Austrian mono-incineration ashes. Without reliable data, the risk of incorrect input data for planning is high.

While two thirds of the energy and the P-recovery potential estimated in this work were derived from the sludge produced at the 10 biggest WWTPs in Austria, it is recommended to also consider WWTPs from smaller size classes ( $\mathrm{PE}<50,000)$ in order to identify and access bigger parts of the energy and P-recovery potentials in Austria. As an example, scenario 1a,b show single mono-incinerators without suppliers (Object ID 2, 18, 23, 40) (Supplementary Materials, Table S12). This does not mean that there are no potential supplier WWTPs in the surrounding area; it only means that none were identified within the target size class. Table 12 visualizes the dimensions of dry solids, ash, and phosphorus that are lost by only focusing on WWTPs with PE $>50,000$. To consider WWTPs with PE $>20,000$ results in a surplus of 80 WWTPs, 16,994 $\mathrm{t}$ of ash, and an additional P-recovery potential of 900-1800 t/a. As the goal is to utilize $65 \%-85 \%$ of Austrian sludge for P-recovery, it is recommended to include WWTPs starting at PE $>20,000$ for further investigation.

Table 12. The amount of population equivalent (PE), WWTPs, and yearly dry solids production is given for size classes from 1 to 50,000 PE. The amount of produced sludge is given in proportion to each size class. The yearly ash produced by mono-incineration and correlation P-recovery potential.

\begin{tabular}{ccccccc}
\hline \multicolumn{7}{c}{$\mathbf{2 0 1 7}$} \\
\hline $\begin{array}{c}\text { Size Class } \\
\text { (PE) }\end{array}$ & PE & Proportion & WWTPs & $\begin{array}{c}\text { Dry Solids } \\
\text { (t/a) }\end{array}$ & $\begin{array}{c}\text { Ash } \\
\text { (t/a) }\end{array}$ & $\begin{array}{c}\text { P-Recovery } \\
\text { (t/a) }\end{array}$ \\
\hline$\geq 1$ & $13,912,495$ & $100 \%$ & 639 & 233,083 & 95,564 & $5200-10,300$ \\
$\geq 2000$ & $13,713,703$ & $99 \%$ & 488 & 229,753 & 94,199 & $5100-10,200$ \\
$\geq 20,000$ & $11,139,998$ & $81 \%$ & 121 & 186,634 & 76,520 & $4100-8200$ \\
$\geq 50,000$ & $8,665,934$ & $63 \%$ & 41 & 145,185 & 59,526 & $3200-6500$ \\
$20,000-50,000$ & $2,474,064$ & $18 \%$ & 80 & 41,449 & 16,994 & $900-1800$ \\
\hline
\end{tabular}




\section{2. $M C A$}

Since a tradeoff situation was identified between decentralized and centralized scenarios according to the MCA, it is important to further investigate both spatial solutions. Fluidized bed incineration technology works best with a large accumulation of yearly sludge, therefore, centralized solutions that utilize high sludge amounts per location should be preferred over decentralized solutions. However, recent discussions in Germany have stated that the fluidized bed mono-incineration should not reach the status of a monopoly technology for sludge treatment $[10,34]$. To find feasible solutions for rural areas with smaller WWTPs, technologies like pyrolysis and hydrothermal carbonization (HTC) need to be investigated, too. Hence, these alternative technologies should be analyzed in the Austrian context in order to obtain a complete picture of the existing development potentials. It would seem advisable to investigate mono-incineration at centralized locations and pyrolysis and HTC technologies for decentralized disposal clusters in rural areas in parallel. Their development is currently restricted due to the legal situation. According to Waste Incineration Ordinances (2015) section 2(1a) and section 7(2), the limiting factor for pyrolysis or gasification technology of sludge is the pollutant concentration in the cleaned gas [35]. Therefore, the pollutant concentration in the cleaned gases has to be collected from different pyrolysis technologies to find out if they are beyond emission thresholds.

Amann et al. [36] requested a countrywide investigation concerning the potential increase of the sewage sludge transport to mono-incineration facilities in Austria. In accordance with the developed decentralized and centralized scenarios, an orientation is given by the following: The decentralized solution results in an average additional sludge transport effort by lorry (24 t) of 6,768,000 tkm/a, and $38,280,000 \mathrm{tkm} / \mathrm{a}$ results for the centralized solutions. To develop efficient regional sludge transport systems, logistics analysis could improve the process and Switzerland already offers a possible solution to compensate sludge transport costs for supplier WWTPs that could be considered in the Austrian context [37]. Results further showed that the inland sludge transport, especially to centralized mono-incineration locations, goes hand in hand with long transport distances that result in high $\mathrm{CO}_{2}$ emissions. Nevertheless, the transport emissions from decentralized and centralized scenarios represent only $0.32 \%-1.8 \%$ of the potential savings in $\mathrm{CO}_{2}$ emissions created by using sludge as renewable fuel in comparison to fossil fuels, which is approximately 86,000 tons of $\mathrm{CO}_{2}$ e./a (Env2). The 86,000 tons of $\mathrm{CO}_{2}$ e./a that could be saved represent a potential ready to be exhausted as soon as the produced mono-incineration energy is consumed. For future investigation in this field, it is important to create $\mathrm{CO}_{2}$ balances that include $\mathrm{CO}_{2}$ neutral transport of sludge. One option in the direction of a more $\mathrm{CO}_{2}$ efficient sludge transport is a combined system (lorry and rail). In comparison to prices for a standard lorry transport, prices for a combined transport system are $250 \%$ more expensive at the moment [37]. This situation leads to the assumption that the railway transport of sludge is, from an economic perspective, not yet feasible.

This research has identified that the existing pretreatment of sludge is important in order to develop spatial solutions. It is important to pretreat sludge to a high technical standard to enhance energy generation potentials and to create flexible management options that reduce the process chain of sludge treatment to the essentials. Any process that is unnecessary should not be included in order to reduce the costs, emissions, and work force needed to operate the process. It is reasonable to dewater sludge to a minimum level of DS 35\% in order to achieve autothermal conditions for mono-incineration without the addition of fossil fuel. Even though the stabilization and dewatering of sludge is already operated by WWTPs in Austria, it is uncertain whether the existing infrastructure of dewatering technology can reach a level of DS $35 \%-45 \%$. If possible, solar drying or even wastewater heat recovery systems could represent promising solutions to achieve higher DS values without the consumption of an external thermal energy source. As high quality pretreatment plays an important role for both transport emissions and possible energy yield, it is crucial to start a participatory process among all supplier WWTP operators, operators of mono-incineration plants, and utilities to deal with excess heat to find solutions. If sludge is dried before the transportation, the transport effort is reduced. Hence, identifying possible sites to utilize waste heat from surrounding industries represents an interesting 
field for further investigation to cope with external thermal energy demand. Further investigation is required into the feasibility of combining the process of drying and mono-incineration locally or into allowing for the separation of both processes.

\subsubsection{Investigation into Future Resource Recovery}

Recent findings from Switzerland [16] indicated that centralized solutions might offer more efficient P-recovery from mono-incineration ash. The findings indicated that the process of P-mining from ash is dependent on size, might create high costs, and is energy intensive. As an example, the feasibility for P-recovery with the presented technology is strongly dependent on access to great loads of thermal energy and mono-incineration ash quantities of around 30,000 t/a [16]. Such ash quantities would lead towards establishing two centralized P-recovery locations in Austria due to the predicted ash amount of approximately 60,000 t. Moreover, the required thermal energy for P-recovery could probably be directly served by a centralized mono-incinerator, which suggests combining the locations of centralized mono-incinerators with a P-recovery facility. In addition to this, findings from Switzerland have shown the potential for other secondary resource recovery combined with P-recovery. Next to phosphoric acid, iron (III) chloride has been recovered in solution at an efficiency of $50 \%$. The iron (III) chloride can be reused as precipitant in the wastewater cleaning processes. In order to justify the complex mono-incineration process, further resource recovery potentials should be tapped.

The sensitivity analysis did not fully answer the feasibility of decentralized or centralized solutions for P-recovery. Whether produced mono-incineration ashes are better utilized in a decentralized or centralized infrastructure is a question that still needs further investigation. Nevertheless, factors like the large demand for thermal energy and ash indicate centralized solutions are more compatible with P-recovery from mono-incineration ash and are more feasible from energy and cost perspectives. As the amount of ash produced for each location has been estimated, the next step is to define the P-recovery strategy. In general, one option is to store the ash in mono-deposits for a later P-recovery, which is not happening yet. Today's P-resources are lost due to the fact that existing mono-incineration ash (Vienna) is polluted by other burning materials [2,38]. Another option is to start pilot projects with a specific P-recovery technology. Ash could theoretically also be sold to private disposal companies, but, in this case, the recovery of P-resources cannot be guaranteed, so this approach should be viewed critically. To further assess P-recovery, a planning process for piloting projects which investigate suitable P-recovery technologies is needed. As an example, for a P-recovery end-product, phosphoric acid $\left(\mathrm{H}_{3} \mathrm{PO}_{4}\right)$ with a concentration of $70 \%$ is a commonly demanded product on the chemical market. The estimated yearly P-recovery potential corresponds to approximately 15,000-30,000 $\mathrm{t} \mathrm{H}_{3} \mathrm{PO}_{4}(70 \%) / \mathrm{a}$. Depending on the origin, the price for phosphoric acid ranges around $700 € / t$, which represents a sales value of $10-21$ Mill $€ / a$. Further investigation into the feasibility of phosphoric acid production is needed. Moreover, economies of scale and ecologies of scale can be noticed [39]: Investment and specific cost decline with big size mono-incinerators (centralized scenarios), but transport demand and emissions grow with mono-incinerator plant size.

\subsubsection{Considering the Spatial Fabric}

A feasibility study addressing P-recovery end products could also determine the characteristics of another important field of investigation: the location factors for P-recovery plants. Location factors can only be analyzed if the inherent process characteristics of P-recovery technology is known. Therefore, location factors and correlating spatiotemporal models should be investigated to find attractive local conditions for future P-recovery facilities.

In the context of mon-incineration as a renewable energy source, even if there is a thermal potential and solutions to harness that potential, this does not mean that the Austrian energy supply system and the system of sludge treatment is able to or intends to adapt to these potentials. The ability for the existing energy and sludge treatment infrastructure to adapt to a new technology, such as mono-incineration, and to answer the question of different spatial solutions for this technology represent 
major challenges for the coming years. From an integrated spatial and energy planning perspective, the energy produced by mono-incineration can be classified as high quality energy (high temperature heat and electricity) that is suitable to be converted into lower quality energy [17]. Even though there is no active integrated spatial and energy planning on a national level yet, initiatives are developing towards that direction. As an example, the Federal Environment Agency Austria asks to include heat consumption matrixes into regional planning acts and to investigate energy certification for municipalities [40]. Additionally, parameters that enhance the feasibility of district heating systems from an integrated spatial energy planning perspective were analyzed by Zach et al. (2019) [41]. They emphasized the utilization of existing and future thermal energy potentials within district heating systems. They further highlighted that there are unused energy recovery potentials due to missing integrated spatial and energy planning initiatives. Hence, to use existing and future energy resources, integrated spatial and energy planning must be included into future planning process.

Thermal energy consumption potentials need to be specified on a smaller regional level, and the existing energy supply infrastructures need to be compared to the energy potentials offered by mono-incineration. The average distance to the next district heating system is approximately $2 \mathrm{~km}$ for both spatial solutions, according to this present work. Further investigation is required to find out about options to connect future mono-incineration facilities to already existing or to new district heating systems. In this course, it is also necessary to investigate options to combine the thermal energy potentials from the mono-incinerator with the anaerobic digestion of sludge to develop combined heat systems [42]. Moreover, the energy utilization potential analysis (En1) was based on projected data from the Austrian heat map, which means it gave an orientation for the energy utilization potentials for a projected development. In the case of an unexpected development in energy demand, it is possible to receive various other results. Industrial or commercial areas, for example, represent major energy consumers, so the construction of such an area within reach of a mono-incinerator has crucial impact on the energy utilization analysis of that specific location. In addition, agricultural purposes such as the heating of greenhouses, the dewatering of agricultural and forest products, the acclimatization of barns, recirculating aquacultures represent potential energy consumers [13].

Sewage sludge mono-incineration can also make valuable contributions to the energy system. When energy demand and energy supply do not overlap, thermal sewage sludge utilization offers potential for increasing the energy supply or minimizing it by means of sewage sludge storage.

\subsection{Strengths and Limitations to the Methodology}

One of the main strengths of this work is the holistic approach that creates a comprehensive picture of the observed system. The integrative scientific approach allows one to combine life-cycle and spatial dimensions that draw a holistic picture about potential roles of mono-incineration in resource recovery and energy supply. Nevertheless, the presented work is also a pioneer study, so the analysis was grounded in rough estimations mainly allowing for strategic choices, not for project planning. The MCA was built upon a few but relevant evaluation criteria. This reduced information demand and information loads on decision makers, but it also calls for more information and further research once it comes to detailed project planning for mono-incineration, P-recovery planning, and P-logistics as well as utilization of excess heat.

The main limitation for the energy balance and the P-recovery estimations was the level of detail in both fields. The energy balance was based on standard values for sludge production, energy outputs, and energy inputs for a variety of different technologies. Using a smaller spatial scale, it would be feasible to include real measurements for sludge production and to calculate an exact energy balance including the specific technical characteristics of the used technology within the observed system. The P-recovery estimations were based on a broad range of P-concentration between 60 and $120 \mathrm{~g}$ $\mathrm{P} / \mathrm{kg}$ ash. Therefore, results should only be used as a first estimation. It would be feasible to conduct real P-concentration measurements with mono-incineration ashes from existing facilities (in Austria, which is the only one in Vienna) to receive a more reliable picture of P-recovery potentials. Moreover, 
the treatment of $\mathrm{P}$ after the mono-incineration was not part of the study. This led to an underestimation of energy demand and related $\mathrm{CO}_{2}$ emissions.

With regard to the scenario development, possible locations for mono-incinerators were determined to be next to existing locations of WWTPs to reduce sludge transport effort. It was not analyzed whether there is enough space to build mono-incineration facilities at each chosen location. Moreover, it is also possible to locate mono-incinerators individually at other locations. Consequently, the scenario development is would have to more detailed in a next step. Location analysis for feasible sites close to the energy consumers could expand the findings of present scenario development.

When interpreting the results of the MCA, it is important to be aware that the choice of evaluation criteria determined which aspects were included in the comparison. In addition, the weighting scheme had a crucial influence on the results. The quantitative evaluation also implied an accuracy that was not guaranteed in every case. The MCA was limited for further differentiation among scenarios resulting in the same total score. For further investigation, it would be feasible to also include evaluation criteria that concentrate on the social acceptance of future developments.

\section{Conclusions}

Based on the presented approach and the case study in Austria, it can be concluded that sustainable sewage sludge treatment should not only optimize the processes of mono-incineration with in the wastewater treatment infrastructure but also take the possibility to deliver energy to the surrounding spatial urban fabric into consideration. By this systematic, holistic approach that combines elements of life-cycle assessment, integrated spatial and energy planning, and multiple-criteria analysis, valuable insights for the planning of resource recovery processes with regards to energy and materials can be generated that go beyond the question if central or decentral mono-incineration is more feasible.

The following key considerations can be derived from this study: First, as the mono-incineration of sewage sludge is not only an expensive but also complex process by itself, not only phosphorus and energy but also other resources should be extracted. Research about further resource recovery options should be advanced. Second, the question if centralized or decentralized options for monoincineration is better suited from a sustainability perspective cannot be clearly answered: From a purely economic perspective, centralized options are more efficient and, hence, much cheaper. Taking environmental considerations into account, they produce a much higher transport demand and related emissions. When considering the urban fabric, they are also able to supply a bigger amount of people and companies with excess heat in district heating networks that would allow for the exhaustion of the energy recovery potentials up to $100 \%$. In decentralized scenarios, this is only possible if the total energy recovery potential can be utilized by combining the built environment with agricultural greenhouse production or process energy demand, e.g., for drying agricultural or forest products. If this can be guaranteed, the decentralized options have environmental advantages over the centralized solutions. Therefore, whether decentralized or centralized solutions are environmentally more feasible depends on local circumstances and project development. In any case, a full exhaustion of the energy supply potentials for the surrounding spatial fabric - no matter if urban or urban and agricultural-is an outstanding criterion to guarantee the sustainability of any mono-incineration process.

Finally, we hope to inspire further research adopting this holistic approach to further national or regional studies about the feasibility of mono-incineration of sewage sludge, as well as to take it as a basis for further scientific advancement. We argue that the whole wastewater treatment infrastructure can be advanced as a key infrastructure for the more climate friendly, energy and resource efficient, and sustainable development of cities, towns, and regions, but only if the perspectives are opened not only to view the wastewater treatment infrastructure itself but also to systematically integrate it in the wider spatial fabric. 
Supplementary Materials: The following are available online at http://www.mdpi.com/2073-4441/12/5/1267/s1, Figure S1. Overall results for alternative A concerning decentralized scenarios (1a, 1b). The score (left y-axis) of each evaluation criteria (En1, En2, Env1, Env2, Co1, Co2, Co3) is shown for all scenarios (D1-D8). The total score (right y-axis) for each scenario is shown by line above the evaluation bars, Figure S2. Overall results for alternative A concerning decentralized scenarios (2a, 2b). The score (left y-axis) of each evaluation criteria (En1, En2, Env1, Env2, Co1, Co2, Co3) is shown for all scenarios (C1-C8). The total score (right y-axis) for each scenario is shown by line above the evaluation bars, Figure S3. Overall results for alternative B concerning decentralized scenarios $(1 \mathrm{a}, 1 \mathrm{~b})$. The score (left y-axis) of each evaluation criteria (En1, En2, Env1, Env2, Co1, Co2, Co3) is shown for all scenarios (D1-D8). The total score (right y-axis) for each scenario is shown by line above the evaluation bars, Figure S4. Overall results for alternative B concerning decentralized scenarios (2a, 2b). The score (left y-axis) of each evaluation criteria (En1, En2, Env1, Env2, Co1, Co2, Co3) is shown for all scenarios (C1-C8). The total score (right y-axis) for each scenario is shown by line above the evaluation bars, Table S1. Value scores for the energy utilization potential (En1), Table S2. Value scores for the additional thermal energy demand for sludge drying (En2), Table S3. Value scores for the CO2 emissions (Eco1), Table S4. Value scores for the substituted $\mathrm{CO}_{2}$ emissions from fossil fuels (Eco2), Table S5. Overview to the investment cost of a mono incineration infrastructure in relation to size classes, Table S6. Value scores for the investment cost (Co1), Table S7. Value scores for the specific costs (Co2), Table S8. Value scores for transport costs (Co3), Table S9. Overall results of the MCA in total numbers, Table S10. Overall results of the MCA for alternative A, Table S11. Overall results of the MCA for alternative B, Table S12. Overview to the $41 \mathrm{WWTPs}$ with PE $>50,000$. The location and the produced yearly sludge amount (rounded to hundreds) is given for each WWTP [28,29], Table S13. Top 10 hotspots of sludge production in Austria, WWTPS PE > 50,000 [29].

Author Contributions: Conceptualization, structure and methodology, D.W., G.N., F.K., and G.S.; data curation and case study analysis, D.W.; writing — original draft preparation, D.W. and G.N.; writing - review and editing, D.W., G.N., F.K., and G.S.; visualization, D.W.; supervision, G.S. All authors have read and agreed to the published version of the manuscript.

Funding: This research received no external funding.

Acknowledgments: This article is based on the Master thesis of the first author titled "Spatial perspectives of sewage sludge mono-incineration" approved at the University of Natural Resources and Life Sciences, Vienna (BOKU) and the Czech University of Life Sciences Prague in 2020. We thank the reviewers for their time to review our manuscript and their valuable comments. The open access funding was provided by BOKU Vienna Open Access Publishing Fund. Thank you!

Conflicts of Interest: The authors declare no conflict of interest.

\section{References}

1. Van Loosdrecht, M.C.; Brdjanovic, D. Anticipating the next century of wastewater treatment. Science 2014, 344, 1452-1453. [CrossRef] [PubMed]

2. Egle, L.; Amann, A.; Rechberger, H.; Zessner, M. Phosphor: Eine kritische und zugleich unzureichend genutzte Ressource der Abwasser-und Abfallwirtschaft—Stand des Wissens und Ausblick für Österreich und Europa. Österreichische Wasser-Und Abfallwirtsch 2016, 68, 118-133. [CrossRef]

3. Wang, X.; Daigger, G.; Lee, D.J.; Liu, J.; Ren, N.Q.; Qu, J.; Liu, G.; Butler, D. Evolving wastewater infrastructure paradigm to enhance harmony with nature. Sci. Adv. 2018, 4, eaaq0210. [CrossRef] [PubMed]

4. Stedman, L. The Wastewater Resource Recovery Facilty of the Future. Water 2015, 21, 41-42.

5. Kretschmer, F.; Zingerle, T.; Ertl, T. Perspektiven der künftigen Klärschlammbewirtschaftung in Österreich. Österreichische Wasser-Und Abfallwirtsch 2018, 70, 579-587. [CrossRef]

6. Kretschmer, F.; Neugebauer, G.; Kollmann, R.; Eder, M.; Zach, F.; Zottl, A.; Narodoslawsky, M.; Stöglehner, G.; Ertl, T. Resource recovery from wastewater in Austria: Wastewater treatment plants as regional energy cells. J. Water Reuse Desalin. 2016, 6, 421-429. [CrossRef]

7. Krüger, O.; Adam, C. Monitoring von Klärschlammmonoverbrennungsaschen hinsichtlich ihrer Zusammensetzung zur Ermittlung ihrer Rohstoffrückgewinnungspotentiale und zur Erstellung von Referenzmaterial für die Überwachungsanalytik. Umweltbundesamt 2014, 49, 27f. Available online: https://ww w.umweltbundesamt.de/publikationen/monitoring-von-klaerschlammmonoverbrennungsaschen (accessed on 28 April 2020).

8. Morf, D.L. Verfahrenstechnische Marktanalyse für die Phosphorrückgewinnung aus dem Abwasserpfad; Office for Waste, Water, Energy and Air (AWEL): Zurich, Switzerland, 2018; p. 100.

9. Jedelhauser, M.; Mehr, J.; Binder, C. Transition of the Swiss Phosphorus System towards a Circular Economy-Part 2: Socio-Technical Scenarios. Sustainability 2018, 10, 1980. [CrossRef] 
10. Kraus, F.; Zamzow, M.; Conzelmann, L.; Remy, C.; Kleyböcker, A.; Seis, W.; Miehe, U.; Hermann, L.; Hermann, R.; Kabbe, C. Ökobilanzieller Vergleich der P-Rückgewinnung aus dem Abwasserstrom mit der Düngemittelproduktion aus Rohphosphaten unter Einbeziehung von Umweltfolgeschäden und deren Vermeidung; Federal Environment Agency (UBA): Berlin, Germany, 2019; p. 393.

11. Hao, X.; Chen, Q.; van Loosdrecht, M.C.M.; Li, J.; Jiang, H. Sustainable disposal of excess sludge: Incineration without anaerobic digestion. Water Res. 2020, 170, 115298. [CrossRef]

12. Hao, X.; Li, J.; van Loosdrecht, M.C.M.; Jiang, H.; Liu, R. Energy recovery from wastewater: Heat over organics. Water Res. 2019, 161, 74-77. [CrossRef] [PubMed]

13. Neugebauer, G.; Kretschmer, F.; Kollmann, R.; Narodoslawsky, M.; Ertl, T.; Stoeglehner, G. Mapping Thermal Energy Resource Potentials from Wastewater Treatment Plants. Sustainability 2015, 7, 12988-13010. [CrossRef]

14. Stoeglehner, G.; Niemetz, N.; Kettl, K.-H. Spatial dimensions of sustainable energy systems: New visions for integrated spatial and energy planning. Energy Sustain. Soc. 2011, 1, 2. [CrossRef]

15. Lichtenegger, K.; Leitner, A.; Märzinger, T.; Mair, C.; Moser, A.; Wöss, D.; Schmidl, C.; Pröll, T. Decentralized heating grid operation: A comparison of centralized and agent-based optimization. Sustain. Energy Grids Netw. 2020, 21, 100300. [CrossRef]

16. Schlumberger, D.S. Phosphor-Mining aus Klärschlammasche. Abschlussbericht zu Handen der Baudirektion des Kantons Zürich'. Stiftung Zentrum für nachhaltige Abfall-und Ressourcennutzung (ZAR). Available online: https://awel.zh.ch/internet/baudirektion/awel/de/abfall_rohstoffe_altlasten/abfall/siedlungsabfaell e/klaerschlamm/_jcr_content/contentPar/downloadlist_3/downloaditems/endbericht_phosphor_.spooler.d ownload.1559561800852.pdf/19_02_04_abschlussbericht_pilotierung_phos4life_public.pdf (accessed on 25 July 2019).

17. Stoeglehner, G.; Neugebauer, G.; Erker, S.; Narodoslawsky, M. Integrated Spatial and Energy Planning; Springer International Publishing: Cham, Germany, 2016.

18. Stoeglehner, G.; Erker, S.; Neugebauer, G. ÖREK-Partnerschaft Energieraumplanung. Ergebnispapier der ExpertInnen. Bundesministerium für Land-und Forstwirtschaft, Umwelt und Wasserwirtschaft. 2014. Available online: https://www.oerok.gv.at/fileadmin/Bilder/2.Reiter-Raum_u._Region/1.OEREK/OEREK_20 11/PS_Energieraumplanung/Ergebnispapier_Energieraumplanung_2014-06.pdf (accessed on 26 July 2019).

19. BAT-WI. Best Available Techniques (BAT) Reference Document for Waste Incineration. European Comission. 2018. Available online: https://eippcb.jrc.ec.europa.eu/reference/BREF/WI/WI_BREF_FD_Black_Watermark .pdf (accessed on 25 September 2019).

20. INTECUS GmbH. Technical Guide on the Treatment and Recycling Techniques for Sludge from Municipal Waste Water Treatment; German Environment Agency: Dessau-Roßlau, Germany, 2016.

21. DWA. Positionen zur Klaerschlammentsorgung. Deutsche Vereinigung für Wasserwirtschaft. 2015. Available online: https://de.dwa.de/files/_media/content/01_DIE\%20DWA/Politikinformationen/Positionspapiere/2 0150324DWAPositionKlaerschlammentsorgung2015final.pdf (accessed on 28 April 2020).

22. Van der Heijden, K. Scenarios. In The Art of Strategic Conversation; John Wiley \& Sons: Hoboken, NJ, USA, 2005.

23. Schwartz, P. The Art of the Long View: The Path to Strategic Insight for Yourself and Your Company; Doubleday Dell Publishing Group: Hoboken, NJ, USA, 1991.

24. Ehrgott, M.; Naujoks, B.; Stewart, T.J.; Wallenius, J. Multiple Criteria Decision Making for Sustainable Energy and Transportation Systems; Ehrgott, M., Naujoks, B., Stewart, T.J., Wallenius, J., Eds.; Springer Berlin Heidelberg: Berlin/Heidelberg, Germany, 2010; Volume 634.

25. Figueira, J.; Greco, S.; Ehrogott, M. Multiple Criteria Decision Analysis: State of the Art Surveys; Springer: New York, NY, USA, 2005; Volume 78.

26. Bättig, M.; Büsser, S.; Frischknecht, R.; Klingler, G.; Küttel, P.; von Schulthess, R. Vergleich verschiedener Entsorgungswege des Klärschlamms aus der Region Luzern mittels Multikriterienanalyse und Ökobilanzen. Bundesamt für Umwelt BAFU. 2011. Available online: https://docplayer.org/27071152-Vergleich-verschiedener-e ntsorgungswege-des-klaerschlamms-aus-der-region-luzern-mittels-multikriterienanalyse-und-oekobilanzen.ht $\mathrm{ml}$ (accessed on 28 April 2020).

27. Bättig, M.; Klingler, G.; Dettli, R.; Frischknecht, R.; Tuchschmid, M. Vorstudie für eine Methode zur Bewertung der Entsorgungs- und Nutzungsverfahren von biogenen Abfällen und Hofdünger. Bundesamt für Energie BFE. 2009. Available online: http://www.news.admin.ch/NSBSubscriber/message/attachments/16126.pdf (accessed on 28 April 2020). 
28. BMNT. Bundes-Abfallwirtschaftsplan 2017. Teil 1. In Bundesministerium für Nachhaltigkeit und Tourismus; Federal Ministry for Sustainability and Tourism (BMNT): Vienna, Austria, 2017; p. 304.

29. EEA. Waterbase-UWWTD. Urban Waste Water Treatment Directive-reported data-European Environment Agency (EEA). Waterbase-UWWTD: Urban Waste Water Treatment Directive-Reported Data. 2019. Available online: https://www.eea.europa.eu/data-and-maps/data/waterbase-uwwtd-urban-waste-water-treatment -directive-5 (accessed on 22 July 2019).

30. DWA. Thermische Behandlung von Klärschlämmen: Monoverbrennung; Deutsche Vereinigung für Wasserwirtschaft, Abwasser und Abfall: Hennef (Sieg), Germany, 2011.

31. Mathiesen, B.V.; Bertelsen, N.; Schneider, N.C.; García, L.S.; Paardekooper, S.; Thellufsen, J.Z.; Djørup, S.R. Towards a Decarbonised Heating and Cooling Sector in Europe-Unlocking the Potential of Energy Efficiency and District Energy; Department of Planning Aalborg University A.C. Meyers Vænge 15, M2 2450: Copenhagen, Denmark, 2019; Available online: https://vbn.aau.dk/ws/portalfiles/portal/316535596/Towards_a_decarbonis ed_H_C_sector_in_EU_Final_Report.pdf (accessed on 31 March 2020).

32. Public Consulting GmbH. Betriebliche Umweltförderung. Förderungsberechnung. Federal Ministry of Agriculture, Regions and Tourism. 2019. Available online: https://www.umweltfoerderung.at/ (accessed on 30 March 2020).

33. Egle, L.; Rechberger, H.; Zessner, M. Endbericht Phosphorbilanz Österreich Grundlage für ein nachhaltiges Phosphormanagement-Gegenwärtige Situation und zukünftige Entwicklung; Bundesministerium für Land- und Forstwirtschaft, Umwelt und Wasserwirtschaft, Sektion VIIWasser Marxergasse 2: Wien, Austria, 2014.

34. Frank, D.; Kraus, F. Irrungen der Klärschlammverordnung: Aktuelle juristische Sicht zur Phosphor Rückgewinnung aus Klärschlamm. Deutsche Phosphor Palttform. Available online: https://www.deutsche-phosphor-plattform.de /pressemitteilung-irrungen-der-klaerschlammverordnung/ (accessed on 2 December 2019).

35. AVV. Gesamte Rechtsvorschrift für Abfallverbrennungsverordnung (Fassung vom 31.12.2015); Federal Legal Information System: Vienna, Austria, 2015.

36. Amann, A.; Zoboli, O.; Krampe, J.; Rechberger, H.; Zessner, M.; Egle, L. Environmental impacts of phosphorus recovery from municipal wastewater. Resour. Conserv. Recycl. 2018, 130, 127-139. [CrossRef]

37. Rytec, A.G. Schlussbericht Logistikkonzept und Transportkostenausgleich Zukünftige Klärschlammverwertung im Kanton Zürich ab Mitte 2015; The City of Zurich: Zurich, Switzerland, 2012; p. 31.

38. Egle, L.; Leutgöb, J.; Schwarzlmüller, E.; Rolland, C. Strategische Umweltprüfung zum Wiener Abfallwirtschaftsplan (Wr. AWP) 2019-2024 und zum Wiener Abfallvermeidungsprogramm (Wr. AVP) 2019-2024 Umweltbericht zur Strategischen Umweltprüfung. 2018 Magistratsabteilung 48-Abfallwirtschaft Straßenreinigung und Fuhrpark. 2018. Available online: https:/www.wien.gv.at/umwelt/ma48/service/pdf/sup-umweltbericht-2018.pdf (accessed on 28 April 2020).

39. Gwehenberger, G.; Narodoslawsky, M.; Liebmann, B.; Friedl, A. Ecology of scale versus economy of scale for bioethanol production. Biofuels Bioprod. Bioref. 2007, 1, 264-269. [CrossRef]

40. Gröger, B. Elfter Umweltkontrollbericht. Umweltbundesamt. 2016. Available online: https://www.umwelt bundesamt.at/fileadmin/site/publikationen/REP0600.pdf (accessed on 28 April 2020).

41. Zach, F.; Erker, S.; Stoeglehner, G. Factors influencing the environmental and economic feasibility of district heating systems-A perspective from integrated spatial and energy planning. Energy Sustain. Soc. 2019, 9, 25. [CrossRef]

42. Hurni, H.; University of Bern. Durchschnittliche Wärmeverluste je Trassenkilometer. Personal communication, 2019.

(C) 2020 by the authors. Licensee MDPI, Basel, Switzerland. This article is an open access article distributed under the terms and conditions of the Creative Commons Attribution (CC BY) license (http://creativecommons.org/licenses/by/4.0/). 